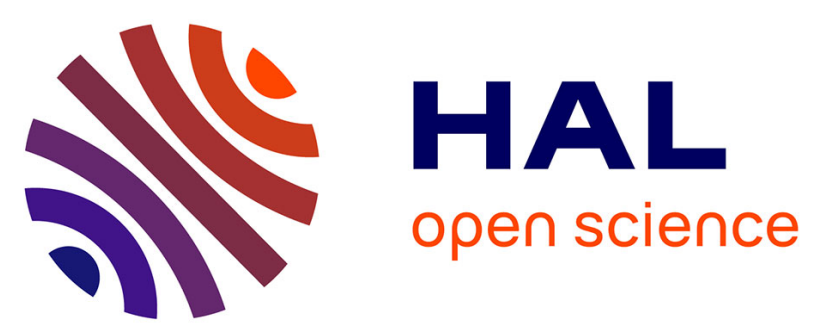

\title{
Late Neogene evolution of the Peruvian margin and its ecosystems: a synthesis from the Sacaco record
}

\author{
Diana Ochoa, Rodolfo Salas-Gismondi, Thomas J. Devries, Patrice Baby, \\ Christian de Muizon, Alí Altamirano, Angel Barbosa-Espitia, David A. \\ Foster, Kelly Quispe, Jorge Cardich, et al.
}

\section{To cite this version:}

Diana Ochoa, Rodolfo Salas-Gismondi, Thomas J. Devries, Patrice Baby, Christian de Muizon, et al.. Late Neogene evolution of the Peruvian margin and its ecosystems: a synthesis from the Sacaco record. International Journal of Earth Sciences, 2021, 110 (3), pp.995-1025. 10.1007/s00531-02102003-1 . hal-03244619

\section{HAL Id: hal-03244619 \\ https://hal.science/hal-03244619}

Submitted on 29 Nov 2021

HAL is a multi-disciplinary open access archive for the deposit and dissemination of scientific research documents, whether they are published or not. The documents may come from teaching and research institutions in France or abroad, or from public or private research centers.
L'archive ouverte pluridisciplinaire HAL, est destinée au dépôt et à la diffusion de documents scientifiques de niveau recherche, publiés ou non, émanant des établissements d'enseignement et de recherche français ou étrangers, des laboratoires publics ou privés. 


\title{
Late Neogene evolution of the Peruvian margin and its ecosystems: a synthesis from the Sacaco record
}

\author{
Diana Ochoa ${ }^{1}$ (1) Rodolfo Salas-Gismondi ${ }^{1,2} \cdot$ Thomas J. DeVries $^{3} \cdot$ Patrice Baby ${ }^{4} \cdot$ Christian de Muizon $^{5}$. \\ Alí Altamirano $^{2} \cdot$ Angel Barbosa-Espitia ${ }^{6,7} \cdot$ David A. Foster $^{6} \cdot$ Kelly Quispe $^{8} \cdot$ Jorge Cardich $^{1} \cdot$ Dimitri Gutiérrez $^{8,9}$. \\ Alexander Perez ${ }^{1} \cdot$ Juan Valqui ${ }^{1} \cdot$ Mario Urbina ${ }^{2} \cdot$ Matthieu Carré ${ }^{1,10}$
}

Received: 21 October 2020 / Accepted: 1 February 2021 / Published online: 9 March 2021

(C) The Author(s) 2021, corrected publication 2021

\begin{abstract}
The highly productive waters of the Humboldt Current System (HCS) host a particular temperate ecosystem within the tropics, whose history is still largely unknown. The Pisco Formation, deposited during Mio-Pliocene times in the Peruvian continental margin has yielded an outstanding collection of coastal-marine fossils, providing an opportunity to understand the genesis of the HCS ecosystem. We present a comprehensive review, completed with new results, that integrates geologi$\mathrm{cal}$ and paleontological data from the last $10 \mathrm{My}$, especially focusing on the southern East Pisco Basin (Sacaco area). We discuss the depositional settings of the Pisco Formation and integrate new $\mathrm{U} / \mathrm{Pb}$ radiometric ages into the chronostratigraphic framework of the Sacaco sub-basin. The last preserved Pisco sediments at Sacaco were deposited 4.5 Ma, while the overlying Caracoles Formation accumulated from 2.7 Ma onwards. We identified a Pliocene angular unconformity encompassing 1.7 My between these formations, associated with a regional phase of uplift. Local and regional paleoenvironmental indicators suggest that shallow settings influenced by the offshore upwelling of ventilated and warm waters prevailed until the early Pliocene. We present an extensive synthesis of the late Miocene-Pleistocene vertebrate fossil record, which allows for an ecological characterization of the coastal-marine communities, an assessment of biodiversity trends, and changes in coastal-marine lineages in relation to modern HCS faunas. Our synthesis shows that: (i) typical endemic coastal Pisco vertebrates persisted up to 4.5 Ma, (ii) first modern HCS toothed cetaceans appear at 7-6 Ma, coinciding with a decline in genus diversity, and (iii) a vertebrate community closer to the current HCS was only reached after 2.7 Ma. The genesis of the Peruvian coastal ecosystem seems to be driven by a combination of stepwise transformations of the coastal geomorphology related to local tectonic pulses and by a global cooling trend leading to the modern oceanic circulation system.
\end{abstract}

Keywords Pisco Basin $\cdot$ Sacaco $\cdot$ Mio-Pliocene transition $\cdot$ Humboldt current system $\cdot$ Faunal turnover $\cdot$ Biodiversity

Diana Ochoa

diana.ochoa@upch.pe

1 Laboratorios de Investigación y Desarrollo (LID), Centro de Investigación Para el Desarrollo Integral y Sostenible (CIDIS), Facultad de Ciencias y Filosofía, Universidad Peruana Cayetano Heredia, Av. Honorio Delgado 430, Lima, Peru

2 Departamento de Paleontología de Vertebrados, Museo de Historia Natural, Universidad Nacional Mayor de San Marcos, Lima, Peru

3 Burke Museum of Natural History and Culture, University of Washington, Seattle, WA 98195, USA

4 Géosciences-Environnement Toulouse, UMR CNRS/IRD/Université Paul Sabatier, 14 Avenue Edouard Belin, 31400 Toulouse, France
5 CR2P (CNRSMNHN, Sorbonne Université), Département Origines et Évolution, Muséum national d'Histoire naturelle, case postale 38, 57 rue Cuvier, 75231 Paris Cedex 05, France

6 Department of Geological Sciences, University of Florida, 241 Williamson Hall, Gainesville, FL 32611, USA

7 Instituto de Investigaciones en Estratigrafía (IIES), Universidad de Caldas, Calle 65 \# 26-10, edificio Orlado Sierra, Bloque B, segundo piso, Manizales, Colombia

8 Programa de Maestría en Ciencias del Mar, Universidad Peruana Cayetano Heredia, Lima, Peru

9 Instituto del Mar del Peru (IMARPE), Dirección de Investigaciones Oceanográficas, Callao, Peru

10 LOCEAN Laboratory, Sorbonne Université (UPMC)-CNRS-IRD-MNHN, Paris, France 

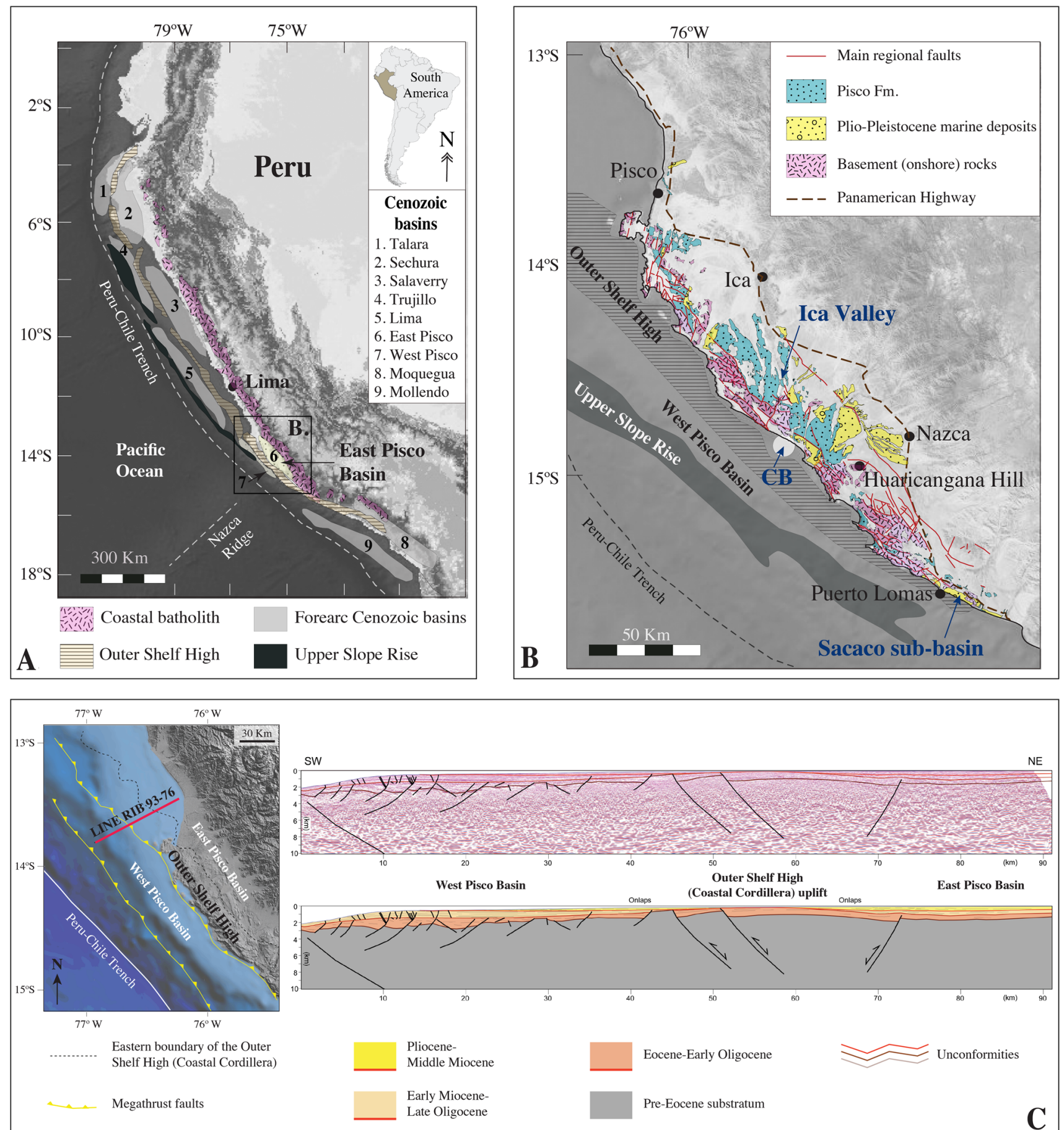

\section{Introduction}

The East Pisco Basin (EPB) is a forearc basin located along the Peruvian continental margin that has accumulated marine sediments since the Eocene (Fig. 1; Thornburg and Kulm, 1981; Dunbar et al. 1990). The uplifted and exposed portion of the EPB comprises extensive Eocene-Pleistocene sedimentary successions that have yielded the most abundant, well-preserved, and diverse vertebrate fossil record of the western South American continental margin. A wide range of coastal-marine fossil remains have been described, documenting the evolution and biogeographic distribution of several living and extinct groups, including cetaceans, pinnipeds, crocodylians, sea birds, sharks, and aquatic sloths (e.g., Muizon and DeVries 1985; Esperante et al. 2008; Bianucci et al. 2016a, b). The giant raptorial 
4Fig. 1 a Major forearc basins existing along the Pacific Peruvian continental margin, including the East Pisco Basin. Dotted areas show the East and West Pisco Basins (numbers 6 and 7). Map modified from Thornburg and Kulm (1981). The Coastal Cordillera corresponds to Outer Shelf High. b Onshore distribution of Mio-Pleistocene marine deposits at the East Pisco Basin mapped according to reports from the Peruvian Geological Service (INGEMMET 2017; maps $31 \mathrm{~m}, 31 \mathrm{n}$, and 32n). Map shows location of the Ica Valley and the Sacaco sub-basin. Location and extension of the Caballas Basin (CB) as originally defined by Couch and Whitsett (1981) is also indicated. Basement rocks includes the Coastal Basal Complex and the Saint Nicholas Batholith. Relief Map source: 30 arc-second DEM of South America (Data Basin Dataset), U.S. Geological Survey's Center for Earth Resources Observation and Science (EROS). c Industrial seismic line RIB 93-76 across the Peruvian Pacific continental margin. From base to top, line shows seismic facies associated with crystalline and sedimentary basement rocks affected by extensional and compressional events. Basement rocks are overlaid by high-frequency reflectors corresponding to the main Cenozoic lithostratigraphic units of the basin (Paracas, Otuma, Chilcatay, and Pisco formations). Reflectors associated with the Paracas and Otuma formations show grabens and half-grabens limited by synsedimentary normal faults. The Otuma Formation is then separated from the overlaying Chilcatay Formation by a regional erosional unconformity that marked the end of the extensional tectonic regime. Growth strata and onlaps in the Chilcatay and Pisco formations recorded the uplift of an antiformal regional structure emerging to the south with the Coastal Cordillera (Outer Shelf High). Modified from Quispe et al. (2018)

sperm whale Livyatan melvillei (Lambert et al. 2010), the aquatic sloth Thalassocnus (Muizon et al. 2003; 2004a), and the penguin Inkayacu paracasensis (Clarke et al. 2010) are only a few of the most outstanding discoveries from the EPB.

Initial reconstructions of the late Miocene-early Pliocene biotic and physical evolutionary history of the EPB have been based on the fossil record from Sacaco (Muizon and DeVries 1985), and have been focused on selected taxa (e.g., invertebrates in DeVries and Frassinetti 2003). This knowledge was only broadly defined due to the limited stratigraphic and chronological control achieved, which occurs for three main reasons. First, rock exposures at Sacaco are highly fragmented, covered by recent eolian material, and have large thickness variations across space (Muizon and DeVries 1985; Brand et al. 2011). Second, the marine micropalaeontological record mostly relies on diatoms that show a tropical and high-latitude mixed signal. Thus, the timing of bioevents may be puzzling, as it varies depending on whether authors use the Equatorial Pacific or the middleto-high-latitude North Pacific zonation (Schrader and Ronning, 1988; Di Celma et al. 2016a; Gariboldi et al. 2017; Solis 2018). Third, although absolute ages using radiometric $\left({ }^{40} \mathrm{Ar} /{ }^{39} \mathrm{Ar}, \mathrm{K} / \mathrm{Ar}\right)$ and isotopic $\left({ }^{87} \mathrm{Sr} /{ }^{86} \mathrm{Sr}\right)$ dating methods are available (Table $\mathrm{S} 1$ ), their exact stratigraphic position is not always well-defined in the Sacaco sub-basin (e.g., Muizon and Bellon 1986), which hinders basin-wide correlations (Brand et al. 2011).
Recently, significant progress was made in characterizing the Miocene stratigraphic record from the Ica Valley in the northern EPB (e.g., Di Celma et al. 2016a, 2017; Gariboldi et al. 2017; Bosio et al. 2019). Lithostratigraphic correlations across 100-m-thick successions kilometers apart were defined and associated with absolute ages. This new calibrated framework has been essential to characterizing the chronology of the depositional phases from the northern EPB, particularly for the middle Mio-Pliocene Pisco Formation. However, chronostratigraphic uncertainties remain for the Sacaco sub-basin. Further efforts to establish reliable depositional ages and basin-wide (north-south) correlations are still required, so that observed biological and geological processes can be properly described and understood. In this paper, we review, analyze, and integrate new and existing paleontological, sedimentological, and radiometric data from the Pisco and Caracoles formations at the southern EPB (Sacaco sub-basin; Fig. 1). We generate a new chronostratigraphic framework for the Mio-Pliocene sediments accumulated at the Sacaco area, which is then used to interpret the sedimentary record and assess the evolution of the southern EPB. We further provide a detailed compilation of the existing vertebrate fossil record for the past 10 million years (My), with an updated taxonomy and stratigraphy. We use this compiled dataset to define genera biostratigraphic ranges and reconstruct the dynamics of the vertebrate faunas inhabiting the Peruvian coastal-marine settings during the last 10 My. Finally, we assess how this late Mio-Pleistocene fossil assemblage compares to modern faunas associated with the Humboldt Current System (HCS), and how the ecosystem evolution is related to local and global environmental changes.

\section{Regional geology and stratigraphical setting}

\section{Definition of the East Pisco Basin}

The EPB starts at $13.5^{\circ} \mathrm{S}$ on the Peruvian continental margin (Travis et al. 1976; Couch and Whitsett, 1981; Thornburg and Kulm, 1981) and extends southward over more than $300 \mathrm{~km}$. It is bounded to the west-southwest by the Coastal Cordillera (Outer Shelf High) and to the east-northeast by the Coastal Batholith (Fig. 1). It progressively becomes shallower towards the south where the Coastal Cordillera shoals forming several small perched depocenters (Thornburg and Kulm 1981; Whitsett 1976). The southern EPB limit is thus not clearly defined, being broadly indicated as $14^{\circ} \mathrm{S}$ (Whitsett 1976) or as $15.3^{\circ} \mathrm{S}$ (Marocco and Muizon 1988; Dunbar et al. 1990; León et al. 2008). Notwithstanding, comparable Miocene sediments (with similar facies and correlatable fossil faunas) can be found from the Cerro Huaricangana in 
the northern EPB ( $15^{\circ} \mathrm{S}$; see Balarezo et al. 1980; Dunbar et al. 1990; Stock 1990; León et al. 2008) up to the Sacaco area (15.2-16 ${ }^{\circ}$ S; see Adams 1906, 1908; Newell 1956; Caldas 1978). These similarities have caused the Miocene sediments to be considered as part of the same basin and so grouped under the same lithostratigraphic unit (i.e., the Pisco Formation; see Adams 1906, 1908; Caldas 1978; Fig. 1b). Whether the Sacaco area was an isolated small basin or was merely a local depocenter part of the larger EPB during the Mio-Pliocene remains elusive. Herein, it will be considered as a small sub-basin of the EPB, containing the southernmost known deposits of the Pisco Formation.

\section{Tectonostratigraphic setting}

The EPB is structurally formed by numerous normal faults and rotated blocks linked to grabens and semi-grabens with predominant NW-SE orientations (Macharé 1987; Alarcón et al. 2005; Rustichelli et al. 2016; Viveen and Schlunegger 2018). The EPB has been first regarded as formed under an extensional regime (Macharé et al. 1986; Macharé and Ortlieb, 1992; León et al. 2008) associated with the Nazca Plate subduction. This view was recently reassessed by Quispe et al. (2018) through integration and reinterpretation of surface and offshore seismic information, indicating that the EPB was under an extensional regime during the Eocene, changing to a compressional setting from the late Oligocene onwards (Fig. 1c). Neogene deformation associated with the Andean uplift generated thrust or reverse faults that induced flexural subsidence and promoted the tilting of some deposits. From the Pliocene onwards, migration of the Nazca Ridge formed a high topographic anomaly and forced the collapse of the sedimentary deposits to find an isostatic equilibrium, generating different responses in the upper crust (Hampel 2002; Espurt et al. 2007).

\section{Lithostratigraphic record of the Sacaco sub-basin}

The successions here reviewed correspond to the last marine sediments preserved in the Sacaco sub-basin (Fig. 1b), excluding the late Pleistocene marine terraces.

\section{The Pisco Formation}

The Pisco Formation is one of the best-known lithostratigraphic units of the EPB because of its abundant and wellpreserved fossils. In contrast to the attention given to the fossil record, the sedimentary and stratigraphic context has received much less consideration in the Sacaco sub-basin. Existing studies have mostly addressed the unit's tectonostratigraphic history using primarily the record from the northern EPB (e.g., Dunbar et al. 1990; León et al. 2008; Di Celma et al. 2017, 2018; DeVries and Jud 2018; Bosio et al.
2020), which consequently has prevented a comprehensive understanding of the spatio-temporal evolution of the fossil record at a basinal scale.

The Pisco Formation discontinuously extends from Pisco up to Yauca (13.5 ${ }^{\circ}-15.6^{\circ} \mathrm{S}$; Adams 1908; Caldas 1978; León et al. 2008) and shows variable thicknesses (200-1000 m; Dunbar et al. 1990; León et al. 2008; Di Celma et al. 2017). It unconformably overlies either Miocene sediments from the Chilcatay Formation, Eocene-toOligocene deposits from the Paracas and Otuma formations, or basement igneous rocks (Caldas 1978; León et al. 2008). The top is capped by Plio-Quaternary alluvial, eolian, or marine deposits corresponding to the Cañete, Changuillo or Huamaní formations in the northern EPB (Petersen 1954; Davila 1989; León et al. 2008), and by the Caracoles or Pongo formations in the Sacaco sub-basin (DeVries 2020). Although at the basin scale, the Pisco Formation appears mostly flat-lying, there is structural deformation, expressed as folding and NW-SE faulting that cuts and displaces strata (e.g., DeVries and Jud 2018).

The Pisco Formation contains various sedimentary facies (e.g., Stock 1990; DiCelma et al. 2017) and a wide variety of lithologies, including (tuffaceous or diatomaceous) siltstones and sandstones, diatomites, cherts, phosphorites, and even dolomites (Dunbar and Baker 1988; León et al. 2008). Based on its lithological features, it was informally subdivided into a lower member dominated by tuffaceous sands and an upper diatomaceous-rich member (Lower and Upper Pisco; see Dunbar et al. 1990; León et al. 2008). In the Sacaco sub-basin, the Pisco Formation predominantly consists of medium-grained massive to plane-parallel sandstones, occasionally interbedded with diatomites, tuffaceous and diatomaceous sandstones, contrasting with the northern sector where diatomaceous beds are regularly present. In the northern EPB, the Pisco Formation is composed of at least three fining-upward, unconformity-bounded transgressive sequences (P0, P1, and P2 in Fig. 2; Di Celma et al. 2017). In the Sacaco sub-basin, only one intraformational unconformity has been reported (Muizon and DeVries, 1985). The unit is interpreted as a coastal to shallow-marine unit deposited across open or protected shoreface and offshore shelf environments affected by waves and coastal upwelling (Dunbar et al. 1990; DiCelma et al. 2016b).

\section{The Caracoles Formation}

This unit was recently described and so far, only identified in the Sacaco sub-basin (DeVries 2020). The Caracoles Formation was defined based on its unconformable boundaries and distinctive lithological features (lesser ash content and finer grained sediments compared to the Pisco and Pongo formations, respectively). It ranges from 30 to $50 \mathrm{~m}$ in thickness, and is composed of green olive-to-brown medium-grained 
massive and bioturbated sandstones, interbedded with indurated coquina beds containing bivalves, gastropods, and barnacles (DeVries, 2020). The unit unconformably overlies the Pisco Formation, and its upper boundary is also an erosive surface with the overlying Pongo Formation (Fig. 2). Sediments from the Caracoles Formation are less deformed relative to the Pisco deposits, and have been interpreted to have accumulated in shallow-marine settings, likely a (semi) restricted embayment, during the late Pliocene-early Pleistocene (DeVries 2020).

\section{The Pongo Formation}

This $70 \mathrm{~m}$-thick lithostratigraphic unit contains the last marine-influenced sediments from the Sacaco sub-basin, exclusive of the late Pleistocene terraces (Macharé and Ortlieb 1992). The Pongo Formation includes two depositional sequences, separated by an intraformational unconformity occurring few meters above an extended and well-developed coquina bed that mainly contains shells of the gastropod Crepidula (DeVries, 2020). Sediments from the Pongo Formation have been considered to be accumulated in coastal environments on high-energy sandy beaches during the Pleistocene (DeVries, 2020).

\section{Geological sections}

\section{Fieldwork data and sampling}

New data presented herein are derived from field observations made along the Sacaco sub-basin (Fig. 3a, b; see Supplementary Information). The composite stratigraphic section presented herein comprises the uppermost beds from the Pisco Formation and the lowermost levels from the Caracoles Formation (Fig. S1). However, geologically older localities (e.g., Aguada de Lomas and Sud-Sacaco), were also surveyed to address Miocene faunas and depositional settings of the sub-basin.

\section{Sacaco locality}

Sediments from the Sacaco locality include the homonymous prolific vertebrate fossiliferous level (SAO) of the Pisco Formation (Fig. 3a; Muizon and DeVries 1985; Brand et al. 2011; Lambert and Muizon 2013). The Sacaco stratigraphic section is $10 \mathrm{~m}$-thick and is primarily composed of a thick yellow medium-grained sandy sequence, intercalated with grey fine-grained tuffaceous sandstones, several shell banks containing Anadara chilensis and Dosinia ponderosa (SB in Figs. 3b, S1), and at least three well-developed tuff levels (see Supplementary Information). The uppermost two tuffs were sampled for $\mathrm{U} / \mathrm{Pb}$ radiometric dating (MG3-25 and MG4-1Mz in Figs. 3f, S1). The MG4-1Mz sample was collected from the same tuff reported by Muizon and Bellon (1980) (Muizon, personal observation). Both samples are part of the Sacaco Monocline described by DeVries (2020) and should correspond to the oldest beds exposed across the Sacaco locality. The overlying Caracoles Formation is only present in the northeastern hills above the valley (see Cerro Amarillo locality).

\section{Yauca locality}

The Yauca succession is located between the villages of Chaviña and Yauca (Fig. 3a). Sediments from the Pisco Formation unconformably sit over igneous basement from the Proterozoic Coastal Basal Complex. The exposed section is $12 \mathrm{~m}$-thick and consists of at least four prominent and indurated shell banks (SB 1-4 in Fig. 3e) with lateral variations to well-cemented, bio-supported whitish sandstone beds containing articulated and disarticulated bivalves and barnacles. Shell banks intercalate with immature grey medium-to-coarse sand beds, that are massive, poorly cemented, and moderately sorted (see Supplementary Information). The section contains a few centimeters-thick, white tuff bed, between the third and fourth most distinctive shell banks (MG-138A in Figs. 3e, S1). The stratigraphic section is capped by recent eolian material or the Panamerican Highway 1S. The contact between the Pisco and Caracoles formations is thus either not exposed or likely not present.

\section{Cerro Amarillo locality}

The Cerro Amarillo locality is situated between the towns of Puerto Lomas and Chaviña (Fig. 3a), and it provides one of the best rock exposures of the upper Pisco and lower Caracoles formations at the Sacaco sub-basin (Fig. 3c). The Pisco Formation consists of alternating fine-to-medium-grained mature sands and tuffaceous sandy beds (see Supplementary Information). Towards the top, sands are replaced by an indurated sandstone bed containing abundant phosphate nodules, shark and ray teeth, and broken bones (Fig. S1). The top of this indurated bed corresponds to an erosional surface marking the end of the Pisco Formation at the Cerro Amarillo locality (Fig. 3c). A $0.3-0.5$ m-thick tuff bed occurs close to the top of the succession (MG3-09 in Figs. 3c, S1).

Above the erosional unconformity, the Caracoles Formation crops out with a gentle northeast $\operatorname{dip}\left(S_{0}=125 / 5\right.$, $n=5$ ) compared to the moderate tilting of the Pisco unit $\left(S_{0}=120 / 12, n=5\right)$. The Caracoles Formation comprises dark-olive, massive to parallel laminated (sandy) silts, interbedded with grey-to-yellowish fine-grained sandstones, and occasional centimeter-thick diatomites, blackish siltstones, 


\section{Existing Chronostratigraphy}

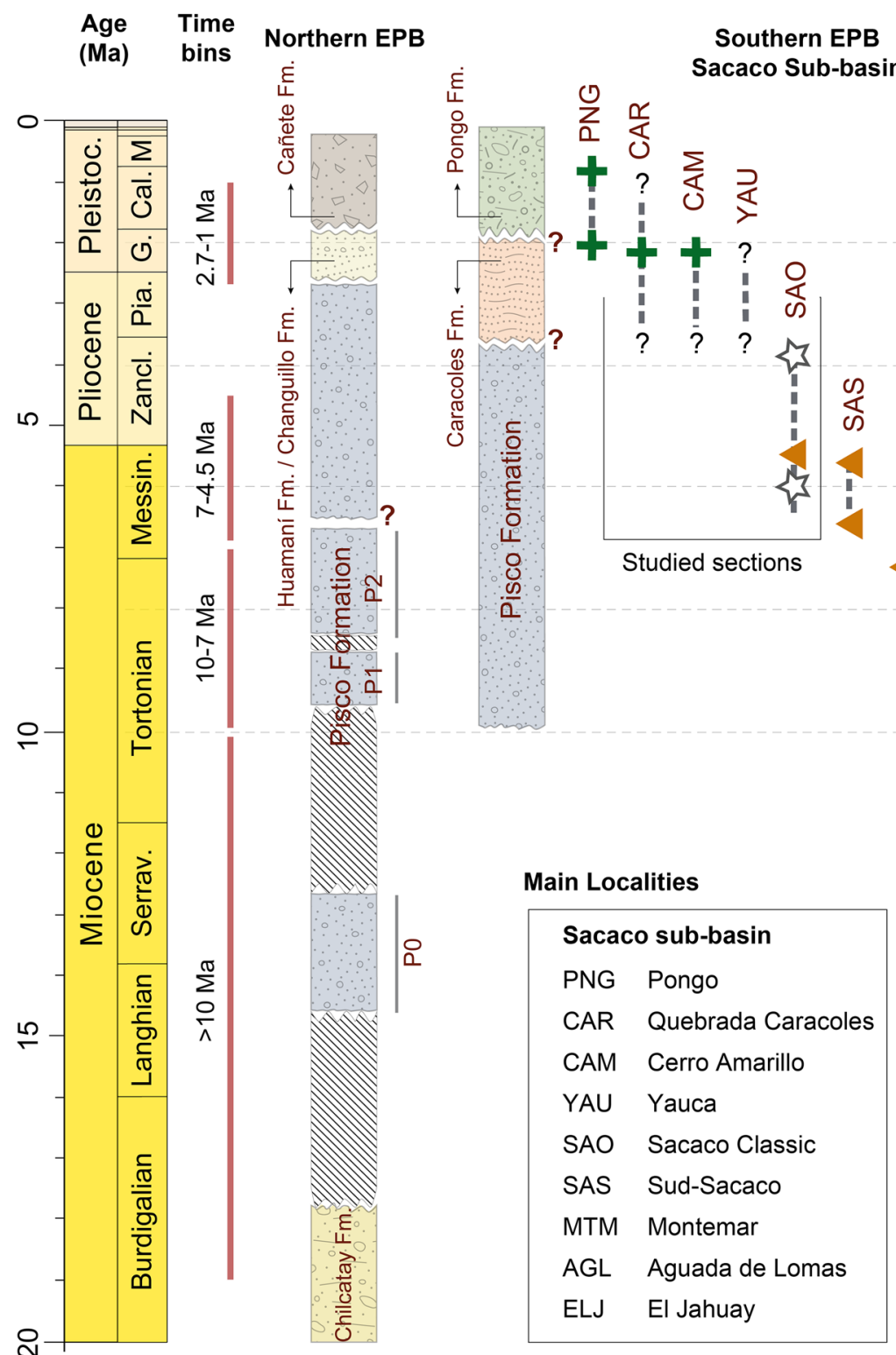

This Study

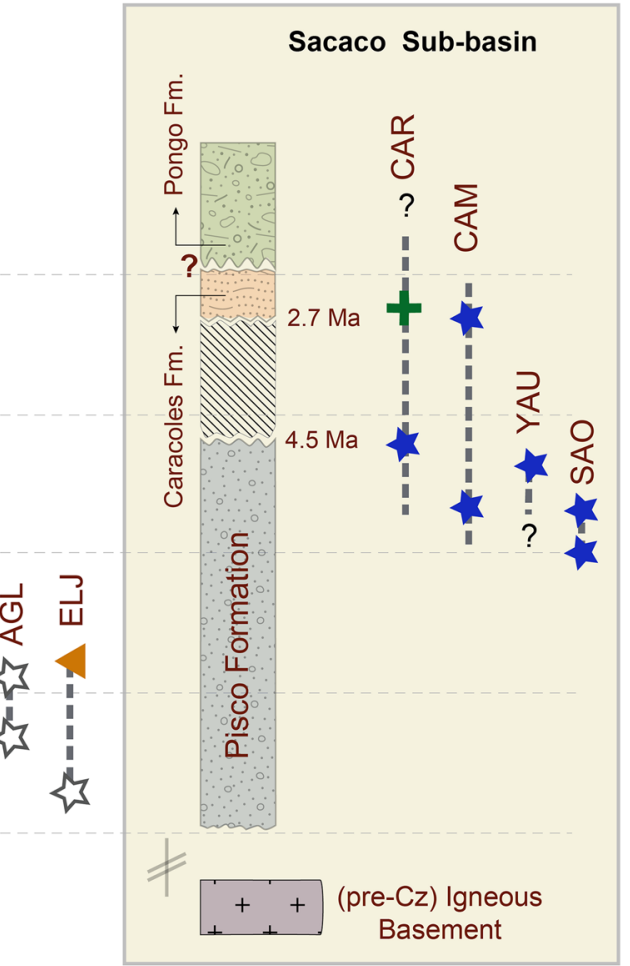

Legend

Radiometric U/Pb dating
Biostratigraphic dating
Hiatus
Time bins used for faunal $/{ }^{86} \mathrm{Sr}$ dating
comparisons

Fig. 2 Existing chronostratigraphic frameworks for the Sacaco subbasin showing known age of main vertebrate fossiliferous localities (Muizon and Bellon, 1980; 1986). Red vertical lines represent time bins used to assess faunal changes throughout time. Stratigraphic sequences: P0, P1, and P2, from the northern EPB are also indicated
(Di Celma et al. 2016a, b; Di Celma et al. 2017; Gariboldi et al. 2017; Bosio et al. 2019). Box to the right shows updated chronostratigraphic framework for the Sacaco sub-basin after this study. * Note that abbreviations refer to localities rather than vertebrate-bearing levels and thin shells banks. Near the base of the formation, a tuff bed occurs (MG3-57 in Figs. 3c, S1).

\section{Quebrada Caracoles locality}

The succession from the Quebrada Caracoles is located along an intermittent stream with the same name, $10 \mathrm{~km}$ WSW of the Bella Union Village (Fig. 3a). The section comprises sediments from the Pisco and the Caracoles formations (DeVries 2020); however, the latter formation presents better exposures (Fig. 3d). The Pisco Formation mainly consists of medium-grained olive sandstones, intercalated with thin fine-grained grey indurated sand beds, tuffaceous sandstones, shell banks, and thin layers of chert and diatomaceous mudstone (Fig. S1; see Supplementary Information). Upwards in the stratigraphic section, beds of 

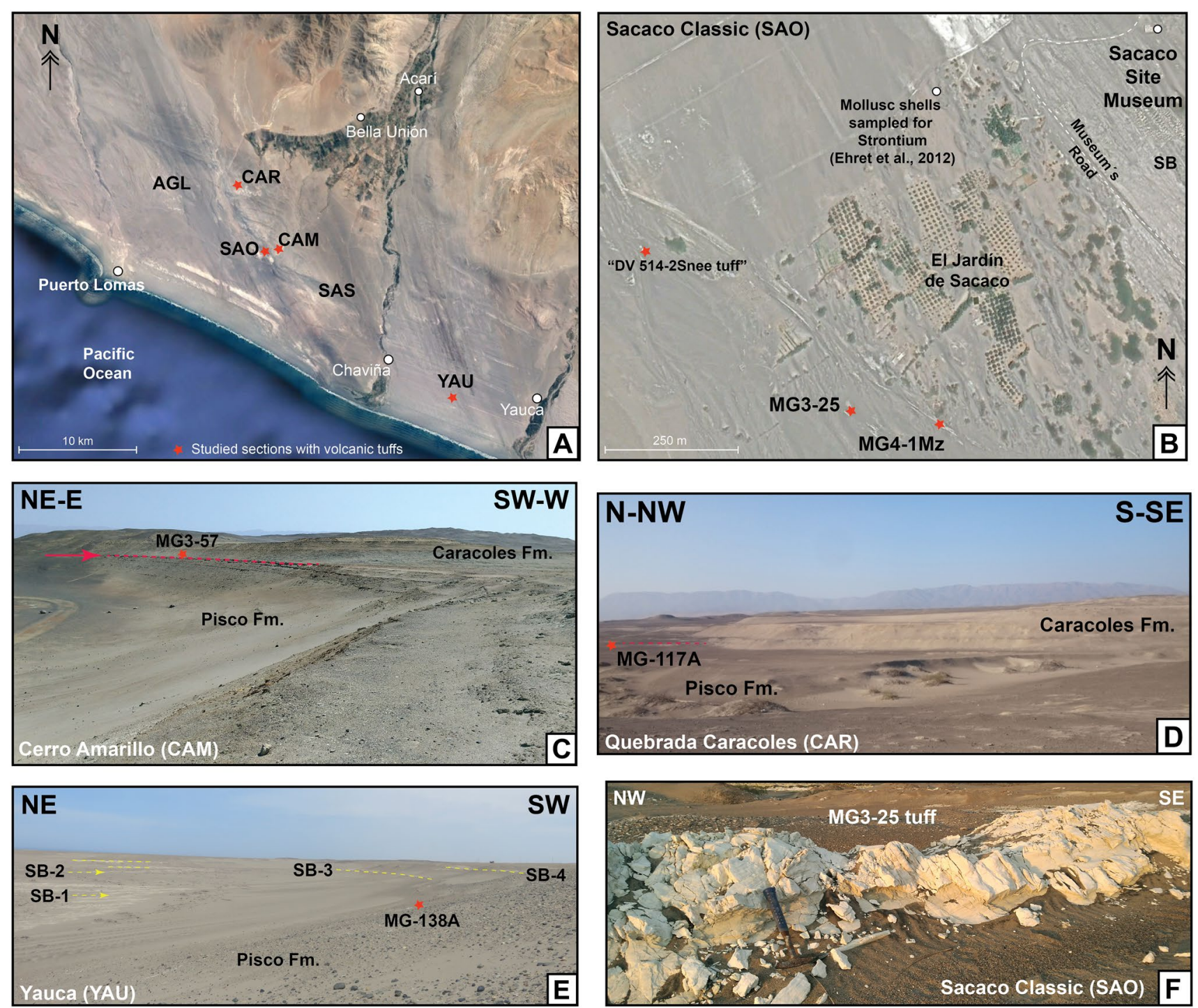

Fig. 3 a Satellite image of the Sacaco sub-basin showing studied localities: Aguada de Lomas (AGL), Sacaco Classic (SAO), SudSacaco (SAS), Caracoles (CAR), Cerro Amarillo (CAM), Yauca (YAU), and location of sampled volcanic tuffs (red stars). b Satellite image of the Sacaco Classic area, showing location of the MG3-25 and MG4-1Mz tuffs (red stars), the latter sample corresponds to the same tuff dated by Muizon and Bellon (1980) (maps in A. and B. adapted from Google Earth). c Unconformity between Pisco and Caracoles formations (red dotted line) at Cerro Amarillo. Red star shows

chert and diatomaceous mudstones become frequent and are associated with a tuff bed that was sampled for $\mathrm{U} / \mathrm{Pb}$ radiometric dating (MG-117A in Figs. 3d, S1). As in the Cerro Amarillo locality, the top of the Pisco Formation is marked by the presence of a massive to nodular-bedded indurated sandstone, containing phosphate nodules, abundant lithic fragments, eroded shark teeth, and fragmented vertebrate bones and shells (Fig. S1). The top of this indurated level, referred to as "Capa de los Dientes" by DeVries (2020), is overlain by a subtle erosional unconformity (Fig. 3D).

stratigraphic location of the MG3-57 tuff. d Unconformity between Pisco and Caracoles formations at Quebrada Caracoles, showing the typical geomorphological appearance of the Caracoles Formation. Red star shows stratigraphic location of the MG-117A tuff. e View of the Yauca section (south to the Panamerican 1S highway). Yellow lines indicate prominent shell banks (SB), red star shows stratigraphic location of the MG-138A tuff. f Close-up view of the MG3-25 tuff (Sacaco locality). Note that abbreviations refer to localities rather than vertebrate-bearing levels

Strike and dip measurements $\left[S_{0}=26 / 8\right.$ for Pisco Formation $(n=10)$ versus $S_{0}=322 / 5$ for Caracoles Formation $(n=5)$ ] reveal that a nearly disconformable contact develops into an angular unconformity towards the northwestern part of the Sacaco sub-basin.

Sediments from the Caracoles Formation overlie the erosional unconformity. At this locality, the Caracoles Formation is well exposed, reaching a total thickness of about $30 \mathrm{~m}$. The lowermost part of the Caracoles Formation (first five meters) locally consists of olive-to-brown 

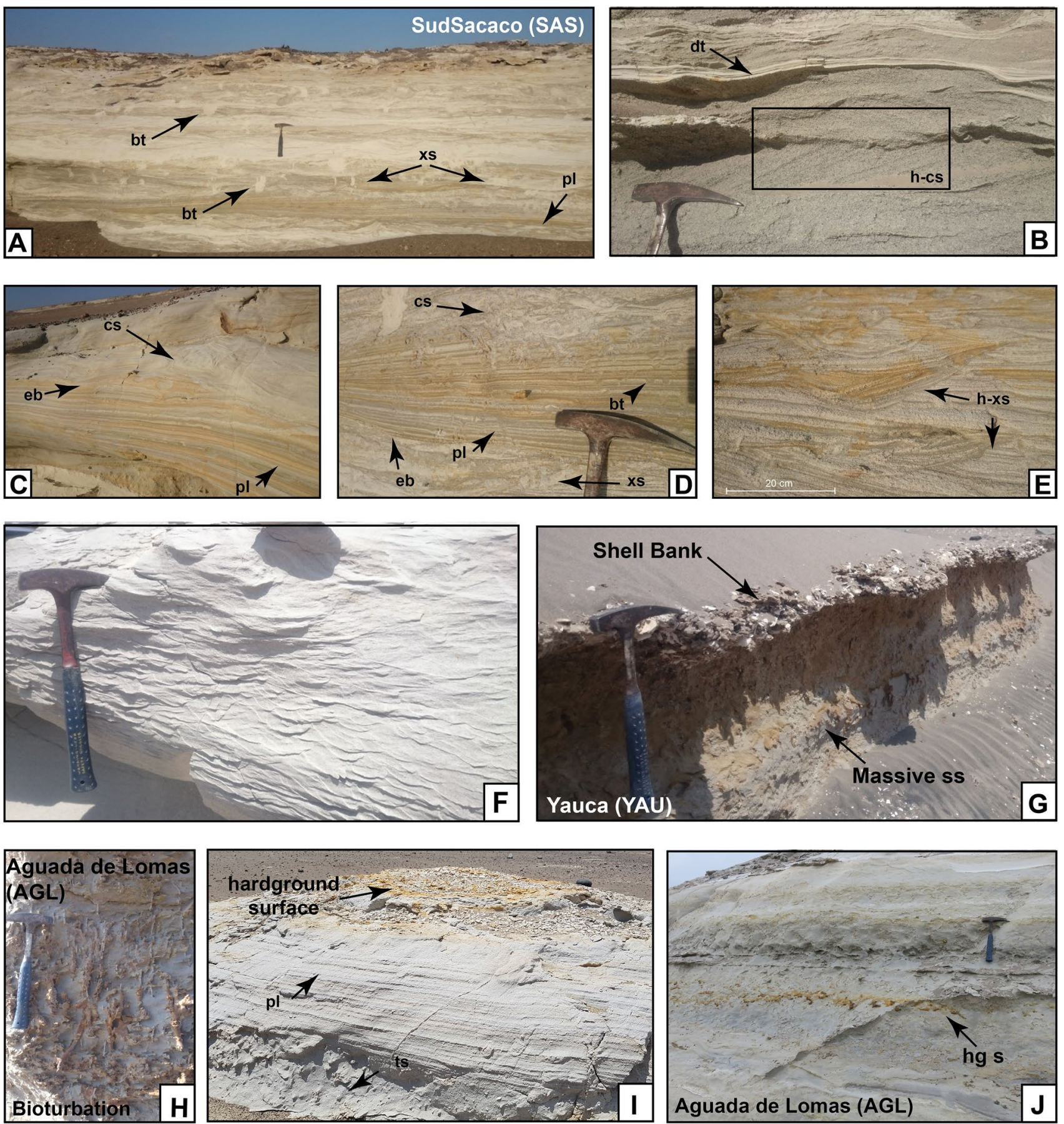

well-cemented sandstones, arranged in tabular bodies without evidence of bioturbation, but with common occurrences of bivalve fragments and molds (see Supplementary Information). The Caracoles Formation continues for another $25 \mathrm{~m}$ until interrupted by an erosional unconformity that places into contact with the overlying Pongo Formation (DeVries 2020).

\section{Sediments of the Pisco Formation in the Sacaco sub-basin}

The total thickness of the Pisco Formation in the Sacaco sub-basin is unknown; however, based on our field observations, a conservative estimate would indicate that the unit is at least $400 \mathrm{~m}$ thick. The sedimentary successions predominantly consist of light grey-to-brownish medium-grained 
4Fig. 4 Details of sedimentary structures and facies present in the Pisco Formation in the Sacaco sub-basin. a Outcrop view of the Pisco Formation at the Sud-Sacaco locality, showing typical irregular (erosive) bases, cross-stratification (xs) and parallel laminations (pl), bioturbation marks (B). b Close-up of herringbone cross-stratified (hcs) mid-to-coarse grained sandstones reflecting deposition in tidally influenced settings, interbedded with finely laminated diatomaceous beds. c Alternating levels of grey, olive and brownish midgrained sandstone layers, showing irregular erosive bases (eb), convolute stratification (cs) and parallel laminations (pl). d Sedimentary structures similar to the ones shown in photo $5 \mathrm{C}$, also showing local bioturbation (bt), large-scale cross-stratification (xs). e Close-up of sandstones showing hummocky cross-stratification (h-xs), typically formed on the shelf, close to the offshore transition zone. f Mediumgrained grey sandstone package with symmetric wave-related current ripples, without bioturbation marks, typically occurring above the storm-wave base. $\mathrm{g}$ Rock exposure facing to west at the Yauca locality, showing massive to slightly bedded medium-grained sandstones with abundant bioturbation, overlaid by a prominent shell bank. $\mathbf{h}$ Close-up of intensively vertically bioturbated sandstones. i Massive tuffaceous sandstone (ts) to the base, irregularly passing to a mediumgrained sandstone package with parallel laminations (pl), finishing upwards with a hardground surface with Fe staining, boring and intense burrowing towards the top. $\mathbf{j}$ Rock exposure showing regular intercalations of parallel to massive beds of grey medium-grained sandstones, intercalated with hardground surfaces (hg s) with boring and burrowing marks

massive to faintly laminated sandstones, interbedded with yellow fine-to-medium-grained heterolithic sandstones, (siliceous-rich) limestones, and diatomites (Fig. 4). Sandstone beds typically have sharp bases that are commonly erosive, laterally discontinuous, and form packages with smooth to distinct fining- and thinning-upward trends (Fig. 4a-e). Sandstone packages containing parallel, cross-, and/or hummocky cross-laminations also occur. Parallel laminations are often accompanied by different scale convolute laminations (Fig. 4c-e). Massive or structureless sandstone beds with abundant bioturbation are also found (Fig. 4g-h). Limestone or very fine-grained sandstone beds are typically grey (Fig. 4f), either finely laminated or lacking internal structures, and with absent or poorly developed bioturbation (Fig. 4j). These architectural characteristics, along with the faunal remains, indicate a great variability of high-energy depositional conditions, varying from wavedominated shoreface ( $>5 \mathrm{mbsl}$ ) to offshore settings ( $>100$ mbsl), with episodes of deposition occurring in the foreshore area as evidenced by the array of sedimentary structures and the occurrence of shell banks (Fig. 4g). Sedimentary structures, such as hummocky cross-stratification, indicate accumulation in wave-dominated infralittoral environments, under processes of turbiditic, longshore wave, or storm-dominated currents (Fig. 4d). Processes related to density flows at stream mouths, turbidity currents (convolute structures present in fine-to-mid-grained sandstones; Fig. 4F), and tidal-influenced currents (herringbone cross-stratification; Fig. 4b) locally occurred as well. Deposition of limestones and/or fine-grained sand indicates phases of relatively low energy (Fig. 4f-j), in which fine suspended particles accumulated by either hemipelagic settling, bottom currents, or fine-grained suspension currents, under low oxygen conditions given the near absence of bioturbation (Fig. 4f). As occurs in the northern EPB, there are dolomite nodules, which would likely have formed under increased porewater alkalinities and $\mathrm{pH}$ due to the reduction of sulfate (Gariboldi et al. 2015; Gioncada et al. 2018). At times of reduced siliceous accumulation and low terrigenous supply, either by rainfall or sea-level changes, sediment starvation occurred, also allowing the formation of phosporite-rich levels.

The Pisco Formation in the Sacaco sub-basin is thus characterized by sand-sized terrigenous clastic deposits, interbedded with (bio)clastic and volcanic-derived deposits (Brand et al. 2011; DeVries, 2020). In the northern EPB, in contrast, sediments with high biogenic siliceous contents predominantly accumulated (e.g., Dunbar et al. 1990; León et al. 2008; DiCelma et al. 2017). Clastic deposits shed into the Sacaco sub-basin from erosion of nearby topographic highs, which mainly included early Miocene sediments ( $20 \mathrm{Ma})$ and Paleozoic basement igneous rocks (Table S3). The distinctive nature of the northern and southern Pisco sediments (diatomaceous-rich versus sand-rich sediments) suggests that by the late Miocene, the Sacaco sub-basin was a shallower depositional area compared to the northern EPB, which could have been acting as an independent depocenter within the EPB.

\section{Updated chronological framework}

\section{Existing chronological constraints}

A breakthrough in understanding the chronostratigraphic framework of the northern EPB successions was recently made by integrating radiometric and diatom-based biostratigraphic data with sedimentological and stratigraphic studies (e.g., Brand et al. 2011; Di Celma et al. 2017; Gariboldi et al. 2017; Bosio et al. 2020). In the northern EPB, at least, three unconformity-bounded sequences for the Pisco Formation have been defined from oldest to youngest as follows: a basal Langhian-Serravallian P0 sequence (14.8-12.4 Ma), a Tortonian P1 sequence ( 9.5-8.6 Ma), and a TortonianMessinian P2 sequence (from $\sim 8.4 \mathrm{Ma}$ to at least $6.71 \mathrm{Ma}$ ) (See Fig. 2; Di Celma et al. 2017; Bosio et al. 2019; 2020). Younger Pisco deposits exposed north of the Ica Valley still need to be integrated into this stratigraphic framework.

The chronostratigraphic framework of the Sacaco subbasin (based on radiometric datings, strontium isotopes datings, and biostratigraphy, Table S1) is in contrast less refined as rock exposures are disconnected and often covered with recent eolian material (see Fig. 3b-d). Ages of the vertebrate levels for this sub-basin are estimated in relation to closely 
located tuffs, isolated ${ }^{87} \mathrm{Sr} /{ }^{86} \mathrm{Sr}$ isotopic measurements and/ or the overall fossiliferous content (Muizon and Bellon 1980, 1986; Muizon and DeVries 1985; Ehret et al. 2012). The stratigraphic succession of fossiliferous localities is, to date, defined as follows: (i) Tortonian sediments occur at El Jahuay (Alto Grande; 9.5-7.46 Ma), Aguada de Lomas ( 8.8-7.9 Ma), and Montemar ( 7.3 Ma); (ii) Messinian deposits at the Sud-Sacaco locality ( 6.6-5.9 Ma); and (iii) Messinian-Zanclean sediments at the Sacaco locality ( 5.89-3.9 Ma) (Fig. 2; Muizon and Bellon 1980, 1986; Ehret et al. 2012). Other fossiliferous localities without absolute ages but considered as Pliocene or Plio-Pleistocene based on their stratigraphic position or paleontological content include: Yauca, Quebrada Caracoles, Cerro Amarillo, Quebrada Pongo, Acarí, and Chaviña (DeVries 2020).

Geographic and/or stratigraphic uncertainties have so far precluded any accurate stratigraphic correlation between locations within the Sacaco sub-basin or with the northern EPB (see Brand et al. 2011). As a consequence of that, controversies remain regarding the relative age, stratigraphic position, and geographic extension of fossiliferous beds and localities in the Sacaco sub-basin (Brand et al. 2011; Lambert and Muizon 2013). We thereafter present an updated and more precise chronological framework for the Sacaco sub-basin based on new radiometric ages.

\section{Dating methods}

Six tuffs were collected along the Sacaco sub-basin (Table 1), five from the Pisco deposits [Sacaco $(n=2)$, Yauca $(n=1)$, Quebrada Caracoles $(n=1)$, and Cerro Amarillo $(n=1)]$, and one from the lowermost known Caracoles sediments (Quebrada Caracoles). ${ }^{206} \mathrm{~Pb} /{ }^{238} \mathrm{U}$ weighted mean ages were used to calculate maximum depositional ages, using a weighted mean of at least the three youngest zircon grains reported with standard error uncertainties at $2 \sigma$ and $95 \%$ confidence intervals (Table 1). Only in the case of samples MG4-1Mz (Sacaco locality) and MG-117A (Quebrada Caracoles) ages were estimated using the two youngest grains. Further details on geochemical analysis and zircon $\mathrm{U} / \mathrm{Pb}$ age determinations are given in the Supplementary Information.

\section{$\mathrm{U} / \mathrm{Pb}$ radiometric ages}

In general, zircon data show a wide range of single grain ages, implying a variety of sources (especially at Quebrada Caracoles and Yauca) and that some tuffs incorporated reworked detrital zircons (Table S3). Given the confidence intervals found in each sample, we interpreted these radiometric ages as representatives of the depositional age of each sampled bed (Table 1). The oldest tuffs correspond to those from the Sacaco locality, with maximum ${ }^{206} \mathrm{~Pb} /{ }^{238} \mathrm{U}$ depositional ages of $5.85 \pm 0.031 \mathrm{Ma}$ and $5.74 \pm 0.056 \mathrm{Ma}$ (MG3-25 and MG4-1Mz; Fig. S4). Note that the latter tuff corresponds to the one reported as $3.9 \pm 0.2 \mathrm{Ma}$ by Muizon and Bellon (1980; see Fig. 3f). The tuff collected below the angular unconformity at Cerro Amarillo (MG3-09) yielded five crystals with a ${ }^{206} \mathrm{~Pb} /{ }^{238} \mathrm{U}$ mean age of $5.645 \pm 0.032 \mathrm{Ma}$ (Fig. S4). The next oldest tuffs were collected at Yauca (MG138A) and Quebrada Caracoles (MG-117A). The former contained 14 crystals with an estimated ${ }^{206} \mathrm{~Pb} /{ }^{238} \mathrm{U}$ age of $4.85 \pm 0.044 \mathrm{Ma}$ and the latter included 2 crystals with an estimated age of $4.541 \pm 0.061 \mathrm{Ma}$. Finally, the youngest tuff occurs a few centimeters above the angular unconformity at Cerro Amarillo (MG3-57), with three crystals indicating an estimated age of $2.7 \pm 0.035 \mathrm{Ma}$ (Fig. S4).

The youngest Pisco sediments thus occur at the Quebrada Caracoles $(4.541 \pm 0.061 \mathrm{Ma})$ and Yauca $(4.85 \pm 0.044 \mathrm{Ma})$ localities (Table 1). These $\mathrm{U} / \mathrm{Pb}$ radiometric ages confirm an early Pliocene age for the uppermost known sediments from the Pisco Formation in the Sacaco sub-basin.

Tuffs from the Sacaco locality yield older mean ages (5.85-5.74 Ma). This age is a robust time constraint, considering the large population $(n=35)$ of similar age zircons found in one of the samples (Fig. S4; Table 1). These results contrast with a K/Ar radiometric analysis by Muizon and Bellon (1980) that estimated the age of the Sacaco locality

Table $1 \mathrm{U}-\mathrm{Pb}$ analyses of zircon for six tuffs sampled in the Sacaco sub-basin

\begin{tabular}{|c|c|c|c|c|c|c|c|}
\hline Locality & Sample ID & Lat & Long & $\begin{array}{l}\text { Weighted mean } \\
\text { age }(\mathrm{Ma})\end{array}$ & Standard error $(\sigma)$ & Confidence interval & Formation \\
\hline Sacaco & MG3-25 & -15.551 & -74.737 & 5.848 & \pm 0.031 & $0.060(n=35 / 36)$ & Pisco \\
\hline Sacaco & MG4-1Mz & -15.551 & -74.736 & 5.741 & \pm 0.056 & $0.706(n=2 / 3)^{*}$ & Pisco \\
\hline Yauca & MG-138A & -15.655 & -74.587 & 4.85 & \pm 0.044 & $0.086(n=14 / 17)$ & Pisco \\
\hline Quebrada Caracoles & MG-117A & -15.502 & -74.754 & 4.541 & \pm 0.061 & $0.119(n=2 / 4)^{*}$ & Pisco \\
\hline Cerro Amarillo & MG3-09 & -15.551 & -74.721 & 5.645 & \pm 0.032 & $0.089(n=5 / 6)$ & Pisco \\
\hline Cerro Amarillo & MG3-57 & -15.551 & -74.722 & 2.7 & \pm 0.035 & $0.68(n=3 / 4)$ & Caracoles \\
\hline
\end{tabular}

Radiometric ages were calculated from the weighted average of a coherent zircon population $(n \geq 3)$, excepting in those samples indicated with

*, whose ages were obtained from the two youngest zircon crystals 
as $3.9 \pm 0.2 \mathrm{Ma}$. Such radiometric age differences are likely related to some argon loss associated with alteration affecting the K/Ar system in biotites. Unfortunately, corrections to the K/Ar ages or updates to the newest standard reference ages for $\mathrm{K} / \mathrm{Ar}$ and ${ }^{40} \mathrm{Ar} /{ }^{39} \mathrm{Ar}$ radiometric ages from Muizon and Bellon (1980) are not possible as parameters, such as the irradiation flux, are unknown. Nevertheless, our results agree with previous strontium-based $\left({ }^{87} \mathrm{Sr} /{ }^{86} \mathrm{Sr}\right)$ isotopic dates yielding an average value of $5.89 \mathrm{Ma}(6.76-4.86 \mathrm{Ma}$; Ehret et al. 2012), as well as with an unpublished $\mathrm{Ar} / \mathrm{Ar}$ date of $5.75 \pm 0.05 \mathrm{Ma}$ (reported by Ehret et al. 2012) obtained from the "DV-514-2 Snee" tuff (Fig. 3f). These combined results imply that preserved sediments from the Sacaco locality (and its associated fossiliferous content) were deposited between 5.7 and $5.8 \mathrm{Ma}$, i.e., almost $2 \mathrm{My}$ earlier than previously thought.

Finally, the oldest known sediments from the Pisco Formation in the Sacaco sub-basin were defined as ranging from 9.6 Ma, based on two K/Ar radiometric ages from $\mathrm{El}$ Jahuay (Alto Grande; Muizon and Bellon 1980). We have demonstrated that the youngest known Pisco sediments occur at Quebrada Caracoles and were deposited during the early Pliocene (Table 1). Hence, the time span encompassed by the Pisco Formation in the Sacaco sub-basin should now be referred to as ranging from $\sim 9.6$ to $4.5 \mathrm{Ma}$ (Fig. 2).

\section{A regional unconformity: evidence of an early Pliocene episode of Andean uplift}

The presence of a hiatus spanning the Mio-Pliocene transition in the northern EPB has been previously documented (Dunbar et al. 1990; León et al. 2008). In the Sacaco subbasin, the uppermost Pisco sediments are capped by an unconformity that places them in contact with Plio-Pleistocene deposits. DeVries (2020) mapped the regional extension of this erosive surface across the sub-basin. The time gap represented by the Pisco-Caracoles unconformity was previously estimated as between 4 and $1 \mathrm{My}$ based on the malacological content (DeVries, 2020). The radiometric ages found below and above the unconformity at Cerro Amarillo (5.6 $\pm 0.032 \mathrm{Ma}$ and $2.7 \pm 0.035 \mathrm{Ma}$, respectively; Table 1) indicate that the angular unconformity represents a time gap of about 2.9 My at this locality. Nonetheless, at the sub-basin scale, the unconformity only represents 1.8 My considering the younger ages found for the Pisco sediments at Quebrada Caracoles $(4.54 \pm 0.061 \mathrm{Ma})$. Furthermore, it remains uncertain whether sediment accumulation was reactivated at the same time $(\sim 2.7 \mathrm{Ma})$ throughout the Sacaco sub-basin.

The unconformity, although of low angle, is angular in nature (generally $5-10^{\circ}$ ), and occurs at the top of indurated brownish layers containing authigenic nodules, phosphatic and calcitic-cemented clasts, basement rock fragments, and abraded vertebrate fossils from the Pisco Formation (Fig. S1; DeVries 2020). Note that these layers display similar lithological features but differ in age. At the Sacaco subbasin, the Pisco beds are often (sub)horizontally lying. However, some late Miocene beds locally exhibit dips of up to 30 degrees along the axis of an N-S monocline structure (Sacaco Monocline of DeVries 2020) that runs for over $10 \mathrm{~km}$. Whether the monocline corresponds to a reactivation fault or an extensional/compressional fault propagation fold is unknown. However, previous works have indicated the presence of a compressional phase affecting the Peruvian coast around $12-16^{\circ} \mathrm{S}$ (e.g., Macharé and Ortlieb 1992). The angular nature of the Pisco-Caracoles surface, along with the presence of a monocline deformation structure, provides evidence for the tectonic origin of this erosional surface and thus can be related to a (local) upheaval event. Such surficial uplift would have subaerially exposed the sediments deposited in the Sacaco sub-basin around 4.5 Ma, promoting their later subaerial erosion.

\section{Paleoceanographic conditions}

\section{Evidence from the sedimentary and fossil record}

Modern oceanographic conditions along the Peruvian continental margin are determined by the coastal upwelling system, which brings to the surface cool nutrient-rich deep waters that promote high rates of primary production (Toggweiler et al. 1991; Pennington et al. 2006), and a permanent shallow Oxygen Minimum Zone (OMZ). The intensity and extent of this OMZ are controlled by high oxygen demand, ocean stratification, and the advection of low-oxygen deep waters (Helly and Levin 2004). Presently, the OMZ extends up to $100 \mathrm{~km}$ offshore and ranges from 50 to $600 \mathrm{mbsl}$ across the Peruvian continental margin (Helly and Levin, 2004; Pennington et al. 2006; Gutiérrez et al. 2009; Salvatteci et al. 2014). However, reconstructions of the OMZ variability during the late Quaternary have demonstrated that its intensity and extent across the continental margin fluctuate at different geological timescales (Arntz et al. 2006; Paulmier and Ruiz-Pino 2009; Gutiérrez et al. 2006; Cardich et al. 2019), showing also a decoupling between oxygen values and paleonutrient proxies (Salvatteci et al. 2016).

The EPB is currently located in front of a strong and permanent upwelling cell $\left(14-16^{\circ} \mathrm{S}\right.$; Tarazona and Arntz 2001). Reconstructing past upwelling and oxygen conditions prevailing during the deposition of the Pisco Formation is needed as this oceanographic feature would dictate the ecological constraints for past marine ecosystems, coastal climatic regimes, sedimentation processes, and possibly the preservation of fossil faunas. The sedimentary record shows 
that silica fluxes were common in the EPB during the accumulation of the Pisco Formation, especially at the northern EPB, where abundant diatomite beds exist (Dunbar et al. 1990; Brand et al. 2004; León et al. 2008). These diatomiterich sequences provide indication of high productivities and frequent upwelling conditions (Marty 1989; Dunbar et al. 1990; Schrader and Sorknes 1991; Abrantes et al. 2007). The Pisco Formation record is, however, less conclusive regarding a paleo-OMZ. Most of the Pisco sediments from the Sacaco sub-basin correspond to silt and sandstones having massive or thick planar- to cross-laminations (Fig. 4; e.g., Muizon and DeVries, 1985) with frequent and abundant horizontal and vertical trace fossils, including ichnofossils such as Thalassinoides, Ophiomorpha, and Gyrolithes (Fig. 4; DeVries, 2020) accumulated under well-oxygenated conditions at the fair-weather and storm-wave base (above $100 \mathrm{mbsl}$ ). It remains unclear whether a permanent OMZ existed at deeper depths (below $100 \mathrm{~m}$ depth). However, the occasional presence of fine-laminated and non-bioturbated limestone and diatomaceous beds in the Sacaco sub-basin indicate sporadic reduced infaunal activity at the seafloor. Furthermore, local occurrences of deep-water dysoxic to anoxic benthic foraminifers' genera, such as Cancris, Valvulineria, and Nonionellina (León et al. 2008), indicate that, besides having episodes of reduced content of dissolved oxygen, the depositional area also underwent deepening phases moving from the inner-outer shelf to the continental slope (below $100 \mathrm{mbsl}$ ). The sporadic occurrence of finelaminated beds and benthic foraminifers evidences that, at those depositional sites, such anoxic events would have been transient, whereas high-oxygen seafloor conditions persisted during most of the deposition of the Pisco Formation at the Sacaco sub-basin ( 10-4.5 Ma). Similar oxic conditions were interpreted for the northern EPB (Esperante et al. 2015).

Therefore, continuous high primary productivity conditions existed in the EPB either related to upwelling or vertical mixing, based on the lithological and sedimentological features of the Pisco Formation. However, such high productivity did not necessarily translate into persistent and extended low-oxygen conditions in those areas from the Sacaco sub-basin where the Pisco sediments were accumulated. It remains unknown if an OMZ was permanently established at greater depths in the continental margin during Mio-Pliocene times, or how oxygen availability in the water column and at sediment-water surface interface did vary in time.

\section{Coastal sea surface temperatures}

Coastal climatic conditions along the Peruvian coast during Mio-Pliocene times are still poorly known. Warmer than present seawater temperatures were inferred for middle
Miocene Pisco sediments based on the presence of warmwater or tropical mollusks and elasmobranch taxa (DeVries and Frassinetti 2003; Bosio et al. 2020). Whilst, cold seawater temperatures were estimated for the late Miocene based on $\delta^{18} \mathrm{O}$ derived from bone phosphates $\left(13-17.2^{\circ} \mathrm{C}\right.$; Amiot et al. 2008). However, the recovery of two extinct longsnouted crocodylian taxa (Piscogavialis and a Tomistominae taxon) from Mio-Pliocene sediments of the Pisco Formation (Table S2) challenges the latter isotope-based temperature reconstructions. Furthermore, remains of a long-snouted crocodylian form were also found in Miocene deposits from Chilean coasts (at $27^{\circ} \mathrm{S}$ in the Bahia Inglesa Formation; Walsh and Suárez 2005). Crocodylians are ectothermic vertebrates limited to warm to temperate aquatic environments (Grigg and Kirshner 2016), so their record is indicative of warm coastal seawaters. Today, the southernmost limit of a crocodylian in the eastern Pacific (i.e., Crocodylus acutus) occurs in northernmost Peru $\left(\sim 4{ }^{\circ} \mathrm{S}\right.$; Thorbjarnarson, 2010), where sea surface temperatures (SST) average 20-25 ${ }^{\circ} \mathrm{C}$ (Ayón et al. 2008). The fossil record of these vertebrates in Peru and Chile (Muizon and DeVries, 1985; Kraus 1998; Walsh and Suárez 2005) thus indicates that late Miocene SST along the Pacific coast $\left(12-28^{\circ} \mathrm{S}\right)$ were substantially higher than today. These warm conditions would have remained at least until $4.5 \mathrm{Ma}$, when the last occurrence of the gavialoid Piscogavialis in the EPB is observed. This fossil evidence is consistent with paleotemperature reconstructions from oxygen isotope analyses performed on late Miocene bivalve shells (Chlamys and Anadara) from the Sud-Sacaco locality that indicate warmer than present temperatures $\left(20-30{ }^{\circ} \mathrm{C}\right.$; Muizon 1981), contrasting with colder values $\left(12-20^{\circ} \mathrm{C}\right)$ obtained from two specimens (Mesodesma and Eurhomalea) from a younger Pleistocene terrace lying above the Pisco Formation (Muizon, 1981).

Open Ocean Connectivity of the Sacaco sub-basin. The EPB is bounded to the west-southwest by the Coastal Cordillera (Outer Shelf High in Fig. 1a), and it remains unclear how this regional topographic feature would have affected the depositional settings at the Sacaco sub-basin, considering its shallower depositional settings compared to the northern EPB. The significant shoaling of the Coastal Cordillera reported from $14{ }^{\circ} \mathrm{S}$ to $16^{\circ} \mathrm{S}$ (Thornburg and Kulm 1981) could have induced (semi)isolated conditions for this subbasin, potentially influencing its temperature and chemistry. Therefore, defining the degree of connectivity of the Sacaco sub-basin with the open ocean is key for determining the influence of the coastal upwelling, local temperature, productivity, and the occurrence of anoxia.

The open ocean connectivity can be assessed to some level using strontium isotope ratios. The residence time of the ${ }^{87} \mathrm{Sr} /{ }^{86} \mathrm{Sr}$ ratio $\left(\approx 10^{6}\right.$ years) in oceanic waters is considerably larger than the ocean water mixing rates $\left(\approx 10^{3}\right.$ years; Hodell and Woodruff 1994; McArthur et al. 2012), and so, 
under normal conditions, strontium isotopic values should be the same in coeval records across the world. In marginal or (semi)isolated basins, the ${ }^{87} \mathrm{Sr} /{ }^{86} \mathrm{Sr}$ ratio is influenced by the continental runoff (ground and surface waters), reflecting the catchment geology and local hydrological dynamics (McArthur et al. 2012). Strontium isotope ratios constrained by independent ages can thus be used to estimate the river water influence and the basin connectivity. To date, five ${ }^{87} \mathrm{Sr} /{ }^{86} \mathrm{Sr}$ estimates exist for the Sacaco sub-basin (Ehret et al. 2012). The strontium isotopic analysis from the Sacaco locality, the only locality containing independent chronostratigraphic controls from $\mathrm{U} / \mathrm{Pb}$ datings, has yielded a mean ${ }^{87} \mathrm{Sr} /{ }^{86} \mathrm{Sr}$ value of 0.7090005 with a $2 \sigma$ error lower than \pm 0.00002 (Ehret et al. 2012). This measured ratio does not deviate from the Messinian average global seawater ${ }^{87} \mathrm{Sr} /{ }^{86} \mathrm{Sr}$ that would correspond to three existing independent radiometric dates (Fig. 5), but it is significantly higher than modern strontium values from coastal rivers entering the Pacific Ocean between 14 and $16^{\circ} \mathrm{S}$, which have catchments dominated by igneous rocks that supply very low ${ }^{87} \mathrm{Sr} /{ }^{86} \mathrm{Sr}$ (ranging from 0.70561 to $0.70809, n=7$; Scaffidi et al. 2020). This indicates that, although the Sacaco sub-basin represents a marginal and shallow area, during the Messinian it did not receive large river inputs with different $\mathrm{Sr}$ isotopic composition, and so major salinity fluctuations due to changes in the freshwater supply were unlikely to occur when the sediments from the Sacaco locality were accumulated ( 5.8-5.7 Ma).

Considering that the late Miocene was likely characterized by increased rainfall in the Central Andean region (e.g., Poulsen et al. 2010; Insel et al. 2012) and the Peruvian margin (Dekens et al. 2007), this result suggests that the connection between the sub-basin and the open ocean was either constant or large enough during the late Miocene ( 5.8-5.7 Ma) to allow for a full mixing with the ocean waters. Therefore, the topographic highs from the Coastal Cordillera may have been protective barriers but did not isolate the Sacaco sub-basin nor significantly restrict the seawater exchange with the Pacific Ocean. This result is supported by a diverse late Miocene molluscan fauna typical of open ocean-facing habitats, that shows no indication of endemic species associated with restricted environments (DeVries 2020), as does occur in modern restricted embayments across the Pacific margin (DeVries and Wells 1990). Further assessment of the basin connectivity and freshwater discharge for other time periods is still needed to understand the sub-basin oceanographic conditions.

\section{The regional and global context}

SST reconstructions from the Eastern and Western equatorial Pacific show $3{ }^{\circ}$ to $5{ }^{\circ} \mathrm{C}$ warmer conditions across the whole Pacific from 10 to $5 \mathrm{Ma}$, with a slightly larger anomaly in the eastern Pacific, indicating a reduced zonal gradient (Zhang et al. 2014) and El Niño-like mean conditions (Wara et al. 2005), which would suggest a reduced equatorial upwelling and cold tongue. On the Peruvian margin, SST reconstructions from the ODP 1237 sediment core show $2{ }^{\circ}$ to $3{ }^{\circ} \mathrm{C}$ warmer conditions from 5 to $3 \mathrm{Ma}$ (Dekens et al. 2007). The lower amplitude of this warming compared to the equatorial Pacific suggests that the coastal upwelling in Peru was already active in the early Pliocene. Climate model simulations of the warm Pliocene climate suggest that the Pacific thermocline was deeper, and that warmer and more ventilated waters were upwelled off Peru (Brierley et al. 2009). These authors also suggest that lower poleward heat transport related to lower SST gradients in that period would have been compensated by a stronger vertical mixing of the ocean. In addition, model experiments showed that lower Andean elevations, similar to the Miocene period conditions, reduce the wind stress and the coastal upwelling strength, especially in southern Peru (Sepulchre et al. 2009). Thus, several lines of evidence suggest that while a coastal upwelling was probably active in Peru during the late Miocene-early Pliocene, it was likely weaker and upwelled warmer and more ventilated waters compared to present day. Such an upwelling could have maintained a high primary productivity and warm-water fauna, but was probably not associated with a strong permanent OMZ off Peru.

\section{The vertebrate paleontological record}

\section{Compiled data and methods}

We systematized data from a wide variety of vertebrate taxa from different evolutionary clades (exclusive of non-tetrapod Osteichthyes), involving a broad range of ecological niches and environmental requirements. Paleontological data were gathered from 20 localities across the northern and southern EPB, spanning from the late Miocene to the middle Pleistocene ( 10-1 Ma). Nonetheless, faunas recorded at the Chilcatay $(\sim 19-17 \mathrm{Ma})$ and lower Pisco formations ( 14-10 Ma) were also reviewed to fully understand regional evolutionary trends. A complete list of all vertebrate fossils reported from each locality with corresponding references can be found in Table S2. Genus richness (incidence-based Chao2 index; Chiu et al. 2014) and per capita rates of origination $(p)$ and extinction $(q)$ using per million-year intervals (Foote 2000), were also calculated to evaluate faunal turnover patterns between 11 and 4.5 Ma. See Supplementary Information for complete details on data compilation, treatment, and diversity analyses.

A reference assemblage of modern coastal-marine vertebrate species living at the Pisco region (13-14.6 ${ }^{\circ} \mathrm{S}$, Table S2) was compiled as a benchmark for assessing past changes in faunal composition with reference to present-day 


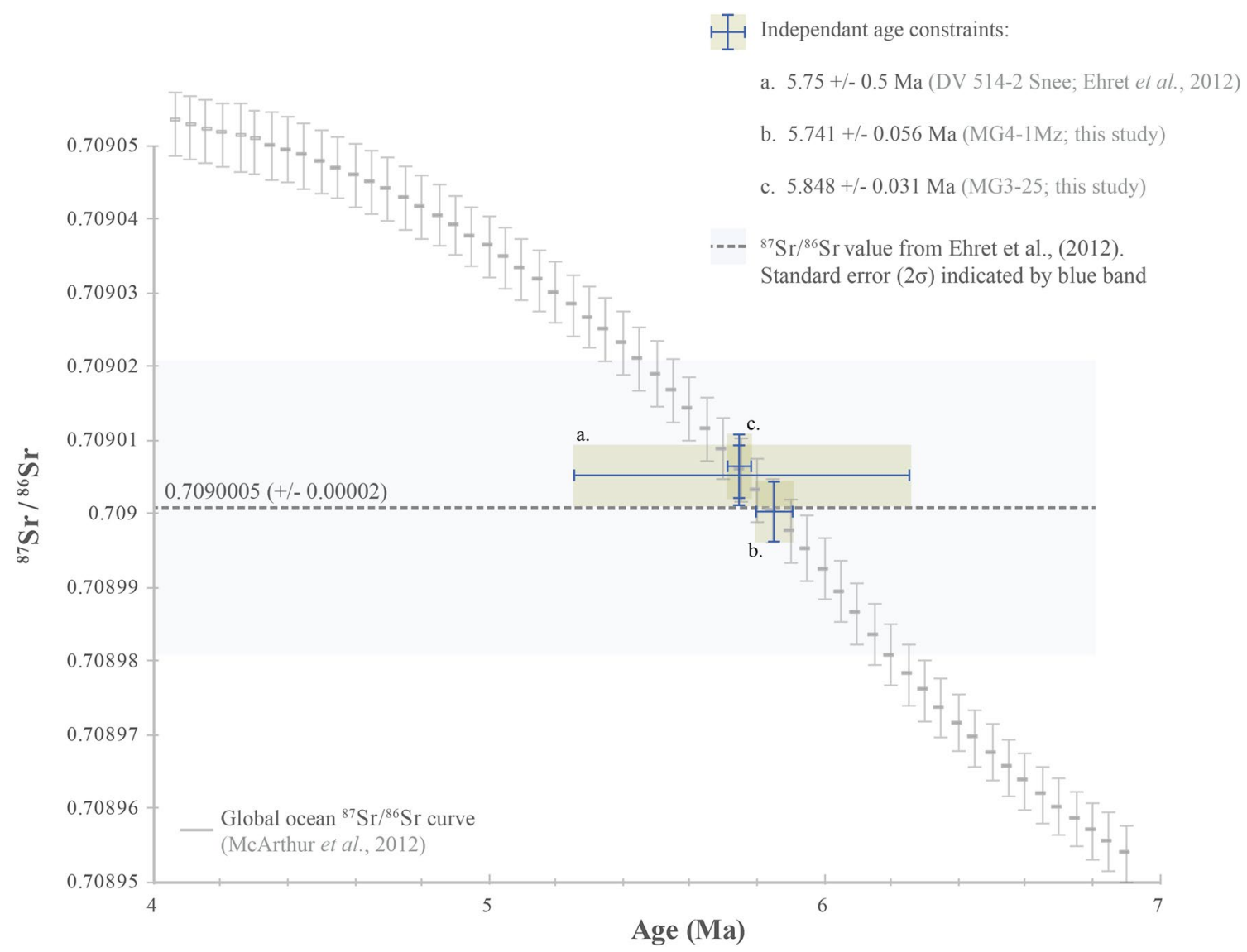

Fig. 5 Global ocean ${ }^{87} \mathrm{Sr} /{ }^{86} \mathrm{Sr}$ ratios for the late Miocene-early Pliocene ( 7-4.5 Ma), data from the LOWESS dataset (V.5; Fit 26/03/13; McArthur et al. 2012). Dotted line shows the strontium isotopic value reported for the Sacaco locality by Ehret et al. (2012) with its $2 \sigma$ estimated error represented by the blue band

HCS communities. This assemblage will be hereafter referred to as Modern Sample (MS). The taxonomic resemblance between fossil and extant vertebrate faunas was estimated by the Simpson Coefficient (SC; Simpson 1960) using presence/absence data. The coefficient quantifies the percentage of shared taxa (here at the genus level) between extant and fossil communities. Minimum and maximum values were estimated, considering that faunal representation of fossil communities is potentially biased by depositional settings or taphonomic processes. The minimum similarity coefficient (SCmin) corresponds to the percentage estimated using the number of shared taxa identified to genus level, whereas the maximum value ( $\mathrm{SCmax}$ ) assumes that fossil specimens identified above the genus level can be assigned to any existing genus from the modern sample (Croft 2007). To estimate this coefficient, fossiliferous localities were clustered in four time bins according to their relative chronostratigraphic position (see Supplementary Information), as follows: Miocene older than $10 \mathrm{Ma}$ (>10 Ma), late Miocene
$(0.7090005 \pm 0.00002)$. Brown boxes show three independent age constraints with error bars $(\mathbf{a}-\mathbf{c})$ for the same locality. Note that independent radiometric ages fall within error of the globally-estimated strontium values

( 10-7 Ma), late Miocene-early Pliocene ( 7-4.5 Ma), and late Pliocene-early Pleistocene (2.7-1 Ma).

\section{Vertebrate paleontology review}

The compiled fossil record comprises a wide taxonomic diversity, including mysticetes, odontocetes, pinnipeds, sirenians, xenarthran sloths, crocodylians, turtles, birds, cartilaginous fishes, and few terrestrial mammals, ranging from the early Miocene to the middle Pleistocene ( 19-1 Ma; Figs. 6, 7). The fossil vertebrate dataset includes 102 taxa, of which 90 are described and named genera (Table S2). The dataset also includes specimens that are not identified at the genus level due to the limited knowledge of some groups, the lack of diagnostic characters, or poor preservation. The most diversified groups are cetaceans (e.g., Piscobalaena, Inkakujira, Brachydelphis, Piscolithax, Ninoziphius, Acrophyseter, and Livyatan; Fig. 6) and chondrichthyans (e.g., Carcharocles, Cosmopolitodus, and Carcharhinus; Fig. 7). 
Pinnipeds and marine birds are also rich groups. Terrestrial mammals such as procyonids, rodents, and continental birds, are scarce and represented by fragmentary evidence. Nontetrapod osteichthyes (bony fishes) although broadly represented (Muizon and DeVries, 1985) were excluded from this review because of the lack of taxonomic and anatomical studies.

\section{Temporal distribution of taxa from $\sim 10$ to $4.5 \mathrm{Ma}$}

The vertebrate assemblages along the late Miocene-early Pliocene ( 10-4.5 Ma) interval remain relatively stable and includes forms of presumably regional distribution. However, variations in taxonomic richness and faunal turnovers within clades can be identified (Figs. 6, 7). A detailed review of the temporal distribution of taxa by phylogenetic groups is available in the Supplementary Information.

Cetaceans. They form a phylogenetically and ecologically diverse group throughout the late Miocene-early Pliocene, comprising at least 36 genera (6 mysticetes and 30 odontocetes; Figs. 6, 8). Beaked whales (Ziphiidae) are abundant in late Miocene sediments ( 10-7 Ma) and are mainly represented by stem taxa mostly belonging to the Messapicetus clade (Bianucci et al. 2016b). Sperm whales (Physeteroidea) are mainly represented by raptorial forms (e.g., Acrophyseter and Livyatan: Lambert et al. 2010, 2016) and pygmy sperm whales (e.g., Koristocetus, Scaphokogia; Muizon 1988; Collareta et al. 2017a; Benites-Palomino et al. 2020), and show no significant changes in taxonomic composition and diversity. In contrast, other odontocete clades, such as beaked whales (Ziphiidae), iniod dolphins (Inioidea), and porpoises (Phocoenidae), experienced a taxonomic turnover at the end of the Tortonian (at $\sim 7 \mathrm{Ma}$; Fig. 6). Odobenocetops, a presumably coastal and endemic form from the southeastern Pacific (Muizon and Domning 2002), became common during the $7-4.5 \mathrm{Ma}$ interval, when the first occurrences of delphinid dolphins are also recorded (Stenella, cf. Delphinus and Cephalorhynchus and/or Lagenorhynchus; Muizon and DeVries, 1985; Fig. 8). Baleen whale remains are abundant during the late Miocene-early Pliocene, however, their taxonomic diversity is poorly known (Brand et al. 2011). Five genera have been documented between 10 and $7 \mathrm{Ma}$, but only two genera are recorded after the Mio-Pliocene transition, the putative cetotheriid Piscocetus, and the extant rorqual Balaenoptera (Fig. 6; Bouetel and Muizon, 2006; Pilleri and Siber 1989). Regarding Piscocetus, its taxonomy and systematics are uncertain since it has been neither revised nor included in recent phylogenetic analyses.

Pinnipeds. Their fossil record includes various well-preserved earless seals specimens (Phocidae) from the northern EPB (Bianucci et al. 2016a, b; Lambert et al. 2017); however, none of them has been properly described and so their taxonomic identity remains uncertain (Lambert et al.
2017). Current evidence suggests the presence of four genera of monachine phocids at the Sacaco sub-basin (i.e., Acrophoca, Piscophoca, Hadrokirus, and Australophoca), being Acrophoca longirostris (Muizon, 1981) the most common taxon (Fig. 6; Table S2). A fifth pinniped taxon, recovered from the Sacaco locality (SAO level), would have also been present (MNHN.F.SAO130). The last record of phocid seal remains occurs at the early Pliocene ( 4.8 Ma; Muizon and DeVries, 1985). No indisputable remains of otariids have been recovered from the late Miocene-early Pliocene (Fig. 6, Table S2). Recent surveys across the Caracoles and Pongo formations (late Pliocene-early Pleistocene) recovered several specimens referable to the living genus Arctocephalus (MUSM 3608, 3628). The holotype of Hydrarctos lomasiensis (MP UNI 04; Museo Mineralógico y Paleontológico de la Universidad Nacional de Ingeniería in Lima, Peru), originally attributed to the living genus Arctocephalus (Muizon 1978), might have been recovered from similar Plio-Pleistocene beds. Lastly, the Caracoles and Pongo formations have also yielded fragmentary bones and teeth of a giant walrus (Odobenidae; Fig. 6; Table S2).

Sirenians. This group is represented by a mandible of the dugongid Nanosiren that was recovered from the Aguada de Lomas locality ( 9.5 Ma; Muizon and Domning 1985; Domning and Aguilera 2008). Along with a roughly coeval isolated tooth from the Bahía Inglesa Formation in northern Chile, these are the youngest records of sirenians in the southeastern Pacific (Bianucci et al. 2006; Domning and Aguilera 2008). Sirenians are obligate aquatic herbivorous and restricted to subtropical and tropical waters (Domning 2001). The body mass of Nanosiren is calculated in $150 \mathrm{~kg}$ and it probably fed upon sea grasses within very shallow waters (Domning and Aguilera 2008; Velez-Juarbe et al. 2012).

Xenarthrans. This group is represented by Thalassocnus, a lineage of marine sloths composed by five species documented from the late Miocene to the early Pliocene ( 10 to 4.5 Ma), being particularly abundant during the late Miocene-early Pliocene (Fig. 6; see Table S2).

Crocodylians and Testudines. The fossil record of crocodylians includes two extinct long-snouted crocodylian forms from different clades: Piscogavialis (gryposuchine gavialoid; Kraus 1998; Salas-Gismondi et al. 2019) and a new taxon identified as a Tomistominae (MUSM 161, MUSM 162). These taxa appear to have distinctive chronostratigraphic distributions. Both are recorded from middle to late Miocene beds ( $7 \mathrm{Ma})$, but only Piscogavialis continues up into the early Pliocene ( 4.5 Ma; Fig. 7). As for testudines, remains of marine turtles have only been recovered from the Ica Valley. The record consists of the cheloniid Pacifichelys urbinai (Parham and Pyenson 2010; Bianucci et al. 2016b) and one dermochelyid species (MUSM 407) more closely 


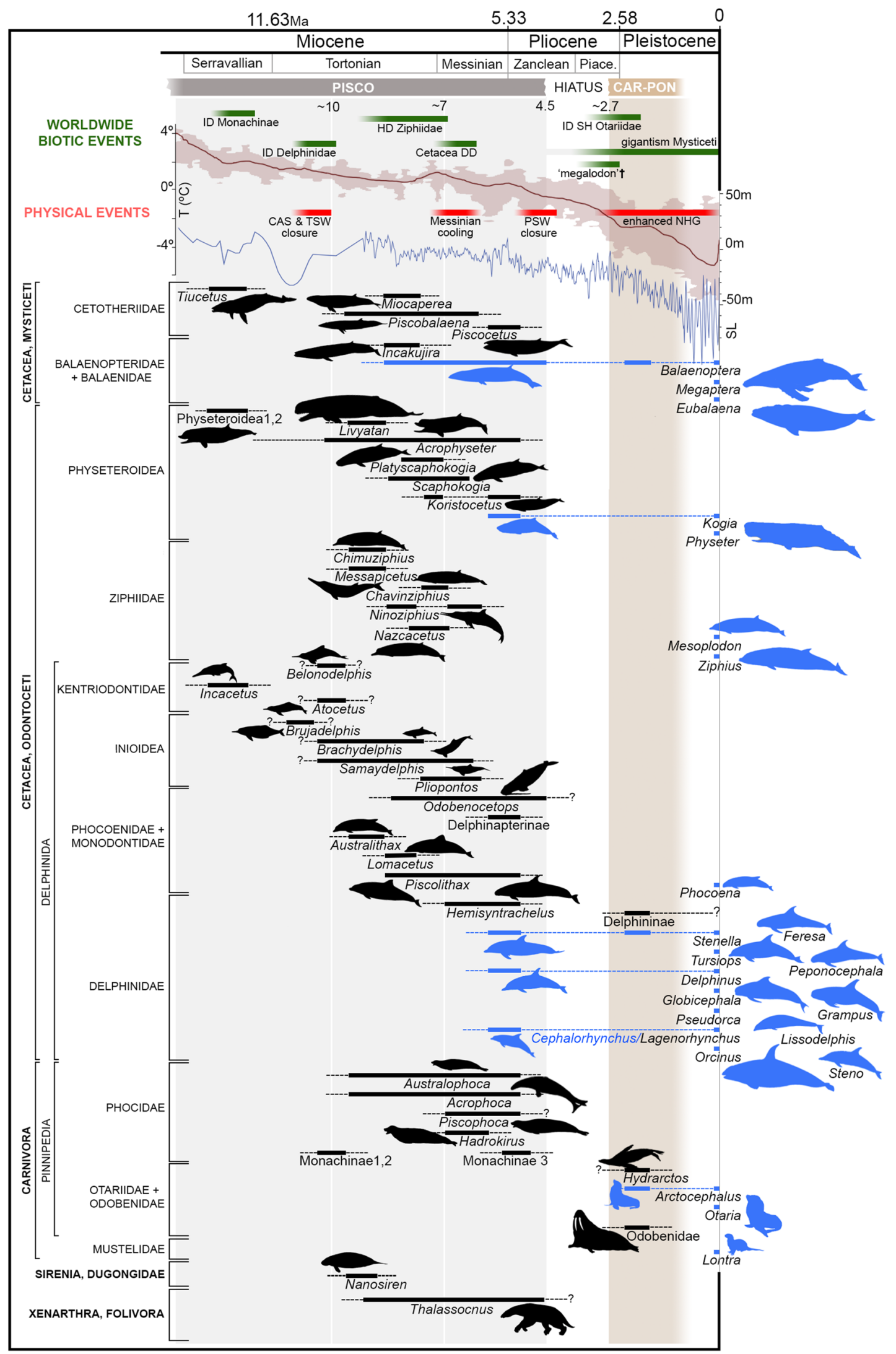


4Fig. 6 Chronostratigraphic distribution of extinct (in black) and extant (in blue) genera of marine mammals recorded over the last $\sim 14$ Ma within the EPB along with those inhabiting the coastalmarine ecosystems of the Humboldt Current System at the basin's latitude. Sea level (SL) curve and global temperature after Miller et al. (2011) and Zachos et al. (2001), respectively. CAR-PONCaracoles-Pongo formations; Piace: Piacenzian, $I D$ Initial Diversification; $H D$ High Diversity; ID SH Initial Diversification Southern Hemisphere; $D D$ Diversification Decline; $C A S$ Central American Seaway; TSW Tethys Seaway; PSW Panama Seaway; NHG Northern Hemisphere Glaciations. $\uparrow$ Last known occurrence

related to Dermochelys than to Psephophorus (J. Parham pers. comm).

Aves. Coastal seabirds, such as boobies (Sulidae), cormorants (Phalacrocoracidae), and penguins (Spheniscidae), are relatively well documented in the Pisco Formation, including several skeletons and hundreds of isolated bones (Fig. 7; see Table S2). In contrast, remains of pelicans are restricted to a single bone occurrence in the Sacaco sub-basin (Montemar locality; Altamirano-Sierra 2013). The Pisco record also includes specimens of extinct taxa of cathartiforms (New World vultures; Stucchi and Emslie 2005; Stucchi et al. 2015a), procellariforms (e.g., petrels, albatrosses), charadriiforms, and other seabirds with no extant close relatives, such as pelagornithids and the sulid Ramphastosula (e.g., Stucchi and Urbina, 2004; Chavez et al. 2007; Stucchi et al. 2015b).

Chondrichthyes. The record is mostly dominated by Carcharhiniformes and Lamniformes (Fig. 7; see Table S2). Teeth of the requiem sharks belonging to Carcharhinus and the lamnid Cosmopolitodus (=Carcharodon) are relatively common, in contrast to those of the lemon shark Negaprion and the sawshark Pristiophorus, which are represented by a few isolated pieces. The non-serrated teeth of Cosmopolitodus hastalis are recorded throughout the late Miocene ( 10-7 Ma) time bin, while teeth with incipient serrations appear in the record for the first time by $\sim 7 \mathrm{Ma}$ (Carcharodon hubbelli type of teeth). Serrated teeth typically of Carcharodon are found from the late Miocene onwards $(\sim 7-1 \mathrm{Ma})$. The otodontid lamniforms, a popular clade known as 'megatooth' sharks, are all extinct and comprise large to giant sharks recovered from the Chilcatay and Pisco formations (Table S2). The giant Carcharocles megalodon was the last survivor of this group and has been recorded up to the top of the Pisco Formation (Bianucci et al. 2016a, b; Muizon and DeVries, 1985; Landini et al. 2017a). To date, Carcharocles is absent from Plio-Pleistocene deposits (Fig. 7). The extant lamnids Carcharodon, Carcharias, and Pseudocarcharias are found as fossils in the Pisco Formation but no longer inhabit the Peruvian coasts. The broadnose sevengill shark Notorhynchus is the only shark from the Caracoles Formation not found in older deposits. Myliobatiformes and Chimaeriformes are restricted to Myliobatis and Callorhinchus, respectively.
Non-aquatic mammals. These remains are rare and have been recovered from late Miocene deposits $(\sim 10-7 \mathrm{Ma}$; Fig. 7; see Table S2). They include elements of the carnivoran procyonid Cyonasua (MNHN SAS 1625, MNHN PPI 262; Muizon and DeVries, 1985; Tarquini et al. 2020), the hystricognath rodent Tetrastylus (MNHN PPI 263, 264), a medium-sized macraucheniid litoptern (MUSM 226), and a small marsupial (MUSM 225).

\section{Diversity trends from $\sim 10$ to $4.5 \mathrm{Ma}$}

The taxonomic richness of the vertebrate assemblage reached its highest values during the Tortonian (10-8 Ma; Fig. 9), ranging from 121.3 to $126.8 \pm 40$ taxa. This high richness appears to be mostly driven by chondrichthyans, after the discovery of a shark tooth-bearing horizon from Cerro Colorado representing a nursery area and which included at least 15 genera (Landini et al. 2017a, b). Cetaceans, although abundant and diverse throughout the record (Fig. 6), do not contribute as much to the observed Tortonian richness (Fig. 9). Lower richness values occur from 8 to $5 \mathrm{Ma}$, when genus richness ranges from 56.6 to $64.5 \pm 6$ taxa. At this time, the entire fossil assemblage shows steady values, but a major drop in cetacean richness is observed in the 6-5 Ma-time bin (11 taxa; Table S2). The Chao2 index was not estimated for the 5-4 Ma-time bin given the small size of the sample (two localities [Yauca and Acarí] accounting for 9 genera).

The dynamics of diversity was further assessed through estimates of origination and extinction per capita rates per million years (Fig. 9). Origination rates are considerably higher from 11 to $8 \mathrm{Ma}$ (values $>0.35$ ), coinciding with the highest richness values. A maximum peak on per capita origination rates occurs at the 9-8 Ma-time bin (0.48). This matches a previous origination peak reported at $9 \mathrm{Ma}$ for marine faunas from the South American Pacific coast (Villafaña and Rivadeneira 2014). From 8 to 4 Ma, origination rates show a marked decrease, while per capita rates of extinction slightly increase and surpass origination rates. A maximum value of extinction rates (0.47) is observed at the 7-6 Ma-time bin, although no change in richness is detected compared to previous and next time bins. Similar patterns (i.e., increase of extinctions and decrease of origination rates) were also described for marine fossil assemblages by Villafaña and Rivadeneira (2014). 


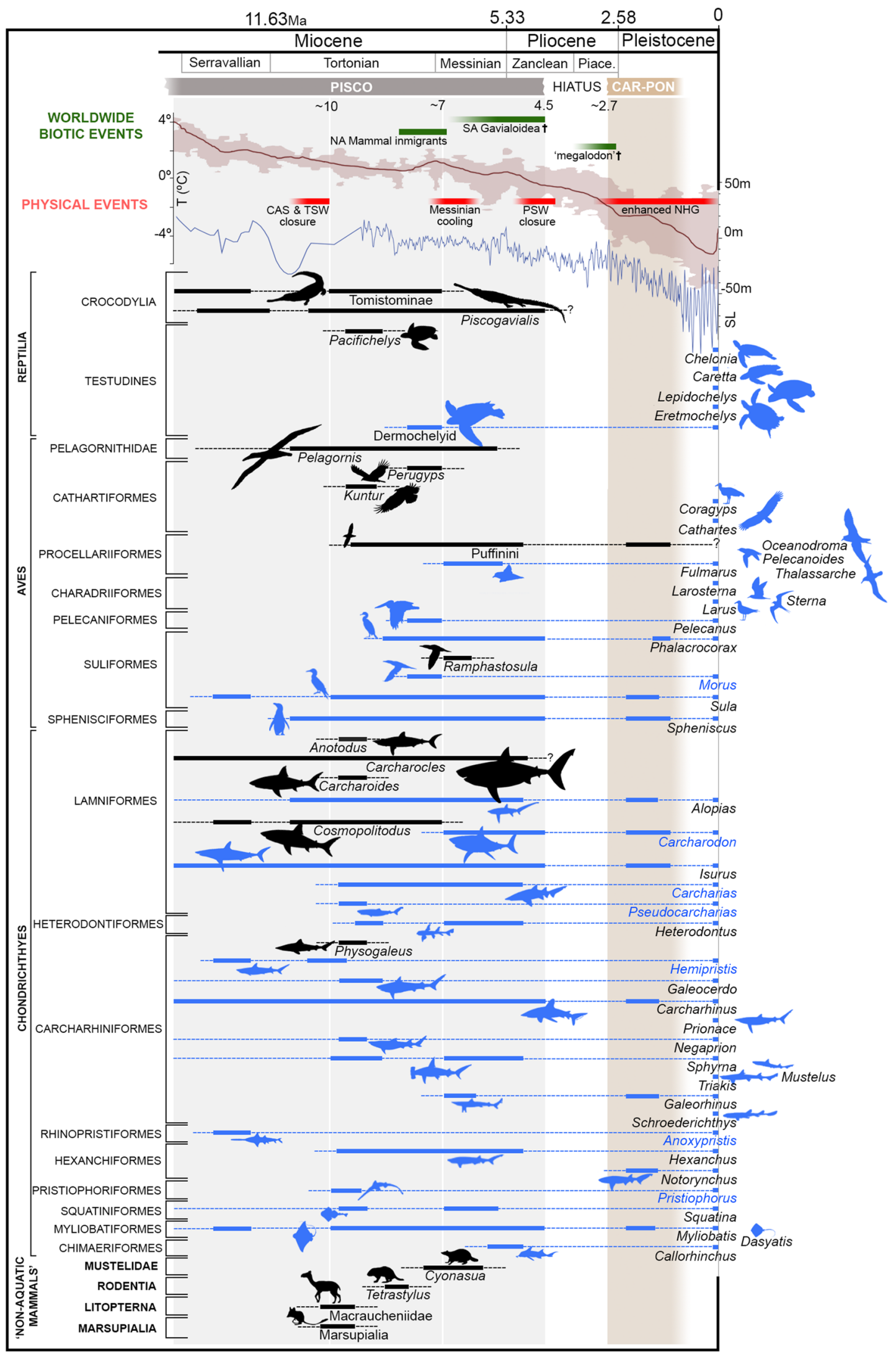


4Fig.7 Chronostratigraphic distribution of extinct (black bars) and extant (blue bars) genera of reptilians, seabirds, chondrichthyans and non-aquatic mammals recorded over the last 14 Ma within the EPB along with those inhabiting the coastal-marine ecosystems of the Humboldt Current System at the basin's latitude. Note that genera in blue designate extant genera living outside the HCS domain. Sea level (SL) curve and global temperature after Miller et al. (2011) and Zachos et al. (2001), respectively. CAR-PON: Caracoles-Pongo formations; Piace: Piacenzian. NA: North American; SA: South American; CAS: Central American Seaway; TSW: Tethys Seaway; PSW: Panama Seaway; NHG: Northern Hemisphere Glaciations. $\dagger$ Last known occurrence

\section{Evolution of the coastal-marine communities from the central Peruvian margin}

\section{Fossil versus Modern assemblages}

A comparison of the reviewed fossil vertebrate faunas to the MS provides an initial understanding on when and how modern taxa became established along the Peruvian Pacific coast. Remains of shark and rays are abundant in the fossil record relative to other vertebrates (Fig. 6), even in outcropping successions with less prospecting effort than those achieved at the traditional Pisco Formation localities (such as Sacaco, Sud-Sacaco, Montemar, and Aguada de Lomas; Muizon and DeVries 1985). This taphonomic feature may bias community assessments (e.g., Boessenecker et al. 2014). Sharks and rays are also known for their reduced evolutionary rates compared with other marine vertebrates (Hara et al. 2018), which could mask changes in ecosystems through time when their record represents an important portion of the whole community. We thus performed two SC estimates, with and without sharks and rays (Table 2).

We compared the fossil fauna present in each of the four time bins previously defined (i.e., Miocene older than $10 \mathrm{Ma}$ [>10 Ma], late Miocene [ 10-7 Ma], late Miocene-early Pliocene [ 7-4.5 Ma], and late Pliocene-early Pleistocene [2.7-1 Ma]; see Supplementary Information) with the MS. Resemblance analysis including sharks and rays provided the following values, from older to younger time slices: $25 \%$, 26.3/29.8\%, 37.2/44.2\%, 70.6/82.4\%. When Chondrichthyes were excluded, the following values were obtained: $4.8 \%$, 13.2/18.4\% 26.7/33.3\%, 70.0/90.0\% (Table 2). The oldest time bin only has one SC value as the minimum and maximum number of shared genera is the same for each analysis. Both analyses show an increasing trend but the values without Chondrichthyes are consistently lower. With or without Chondrichthyes, analyses indicate a moderate rise in the resemblance with the MS from the late Miocene $(\sim 10-7 \mathrm{Ma})$ to the late Miocene-early Pliocene time slice ( 7-4.5 Ma) (Table 2). This is led by the first putative record of conspicuous representatives of the modern HCS community among odontocetes, such as the delphinid dolphins Stenella and cf. Delphinus, Lagenorhynchus, and the pygmy sperm whale
Kogia (Fig. 8; Benites-Palomino et al. 2021). Some marine birds (Spheniscus, Phalacrocorax) and the rorqual Balaenoptera occur since $10 \mathrm{Ma}$ (Figs. 6, 7). Among chondrichthyan fishes, the Mio-Pliocene ( 7-4.5 Ma) fauna includes the earliest record of the great white shark Carcharodon, the school shark Galeorhinus, and the chimaera Callorhynchus. However, disregarding the potential taphonomic bias driven by the overrepresentation of chondrichthyans, analysis suggests that less than $40 \%$ of the genera diversity of modern coastal-marine environments from the HCS was present before $4.5 \mathrm{Ma}$, when the latest known Pisco paleoenvironments are documented (Figs. 6, 7; Table 2). Late colonizers of the HCS, are either reported from the Caracoles and Pongo units (eared seals: Otariidae), or have no fossil record to date in the EPB (e.g., the porpoise Phocoena, the humpback whale Megaptera, and the marine otter Lontra).

\section{Faunal Turnover: Progressive changes over the last 10 My}

Our analyses of faunal similarities along with estimates of per capita origination and extinction rates identified selective faunal turnovers between time bins over the last 10 My (Table 2; Fig. 9). In general, differences are driven by changes within marine mammal communities, primarily within odontocetes and pinnipeds (Fig. 6). As high trophic level vertebrates (Pauly et al. 1998), changes in their assemblages through time might reveal shifts in productivity, type of resources, and functioning of the ecosystem (Tucker and Roger 2014; Pyenson and Vermeij, 2016). Here, we analyze the main faunal changes between time bins and discuss putative patterns of turnover related to tectonics and global climate trends.

\section{0-7 Ma: morphological diversification of crown delphinidans and dawn of endemic taxa}

Basal odontocetes with double-rooted cheek teeth (e.g., Inticetus), platanistoids (e.g., Huaridelphis, Macrosqualodelphis), and archaic delphinidans (e.g., Incacetus, Atocetus, 'Kentriodontidae') experienced a demise at $10 \mathrm{Ma}$ or much earlier within the EPB (Colbert 1944; Muizon 1988; Lambert et al. 2017; Bianucci et al. 2018, 2020). Some platanistoids and 'kentriodontids', however, did survive longer in isolated marine and freshwater settings (Ichishima et al. 1994; Marx et al. 2017), as the South Asian river dolphin Platanista, the only extant representative of the platanistoids (Barnes et al. 2006). The earliest record of sperm whales (Physteroidea) in the EPB includes the basal taxon Raphicetus valenciae from Chilcatay sediments (Lambert et al. 2020b) and two undescribed forms from the lower Pisco Formation (Di Celma et al. 2017, 2018; Lambert et al. 2020a; Table S2). 


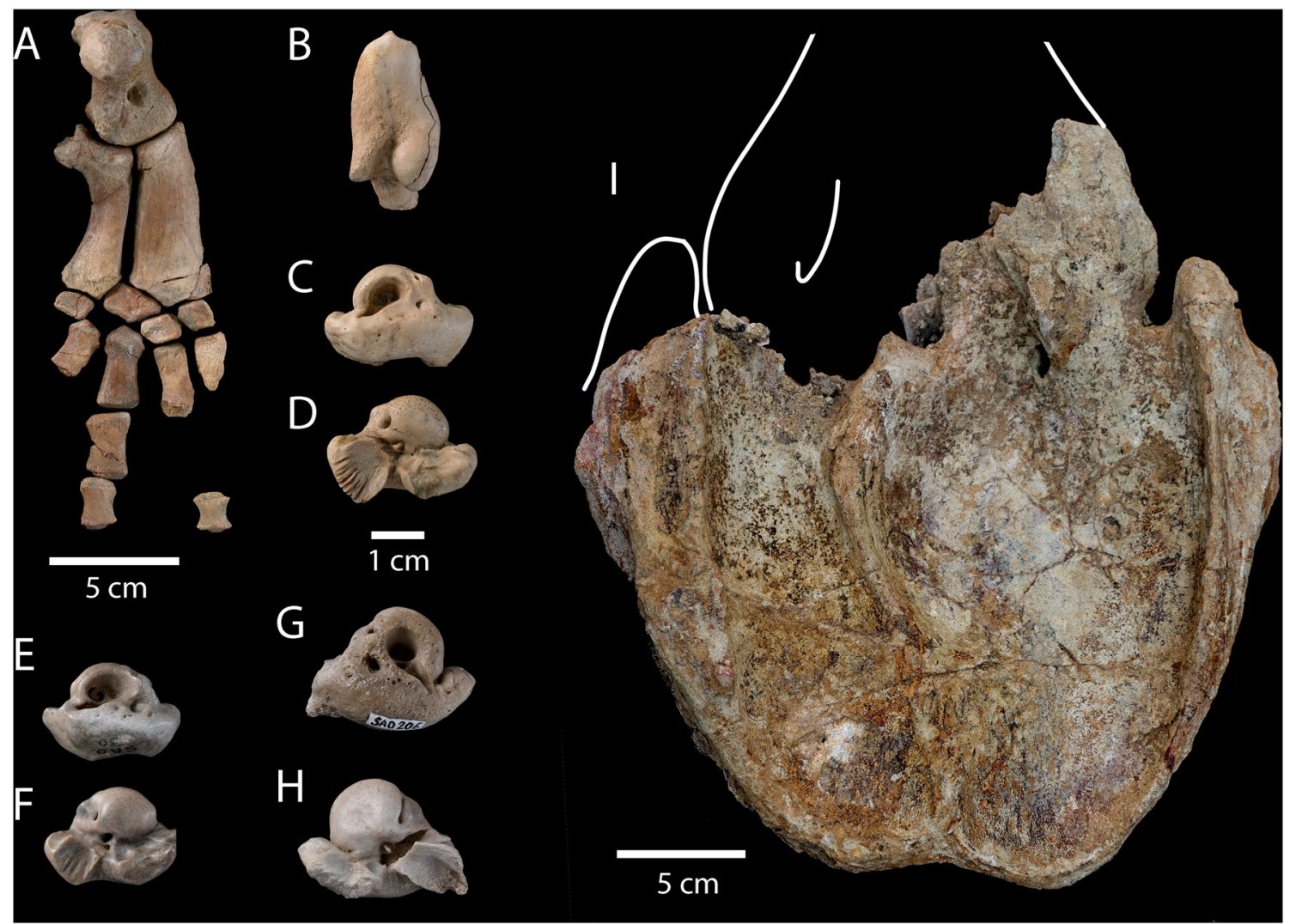

Fig. 8 Selected toothed cetaceans from the Sacaco locality. a-d cf. Delphinus sp. (MNHN.F.SAO 211): left arm in ventral view (a), right tympanic bulla in ventral view (b), periotic in dorsal (c) and ventral (d) views. e, f Cephalorhynchus or Lagenorhynchus (MNHN.F.SAO

Although similarity values relative to the MS show a low increase between the oldest time bins (from 4.8 to $13.2 / 18.4 \%$ ), profound changes in the marine communities did occur at $\sim 10 \mathrm{Ma}$ (Figs. 6, 9). For instance, the late Miocene ( $\sim 10-7 \mathrm{Ma})$ time bin is also characterized by the first record and large diversification of beaked whales (Ziphiidae) and dwarf sperm whales (Kogiidae), as well as crown delphinidan subclades, such as porpoises (Phocoenidae) and toninhes (Pontoporiidae). Prior to $\sim 10 \mathrm{Ma}$, several groups of odontocetes possessed a long-snouted morphotype, including longirostrine and hyperlongirostrine forms in marine environments (Bianucci et al. 2020; Norris and Mohl 1983). After the evolution of crown delphinidan subclades, odontocete snout shape diversified and reached putative specializations in feeding strategies (Fig. 9; Werth 2006; Boessenecker et al. 2017). The late Miocene ( 10-7 Ma) assemblage of the Pisco Formation exemplifies the extraordinary disparity of odontocete snout shapes in coastal environments (Fig. 6), including a wide range of long-, blunt-, bulky-, and short-snouted forms (Muizon 1988; Collareta et al. 2017a;
30): periotic in dorsal (e) and ventral (f) views. G-H. Delphinapterinae indet. (MNHN.F.SAO 206): periotic in dorsal (g) and ventral (h) views. i Kogia (MUSM 3888): partial cranium in dorsal view

Benites-Palomino et al. 2020). This morphological disparity might be associated with a global peak in cetacean diversity and speciation rate reached during Tortonian times (Fig. 9), which could have been driven by a burst in diatom diversity associated with global marine productivity (Steeman et al. 2009; Marx and Uhen 2010). Although true dolphins (Delphinidae) might have already diversified by the late Miocene (Steeman et al. 2009; Bianucci et al. 2013; Murakami et al. 2014), no delphinid remains have been recovered from late Miocene ( 10-7 Ma) sediments in the EPB (Fig. 6).

The late Miocene ( $\sim 10-7 \mathrm{Ma})$ time bin also marks the dawn of endemic forms, such as the aquatic sloth Thalassocnus and the walrus-like delphinidan Odobenocetops (Fig. 6). Both taxa, along with other vertebrates (e.g., the pontoporiid Brachydelphis, the long-snouted seal Acrophoca, the penguin Spheniscus, and crocodylians), have also been recovered from the northern coast of Chile (Walsh and Naish 2002; Canto et al. 2008; Gutstein et al. 2009; Pyenson et al. 2014; De los Arcos et al. 2017), suggesting that the southeastern Pacific coastal areas $\left(\sim 14-25^{\circ} \mathrm{S}\right)$ have shared similar 


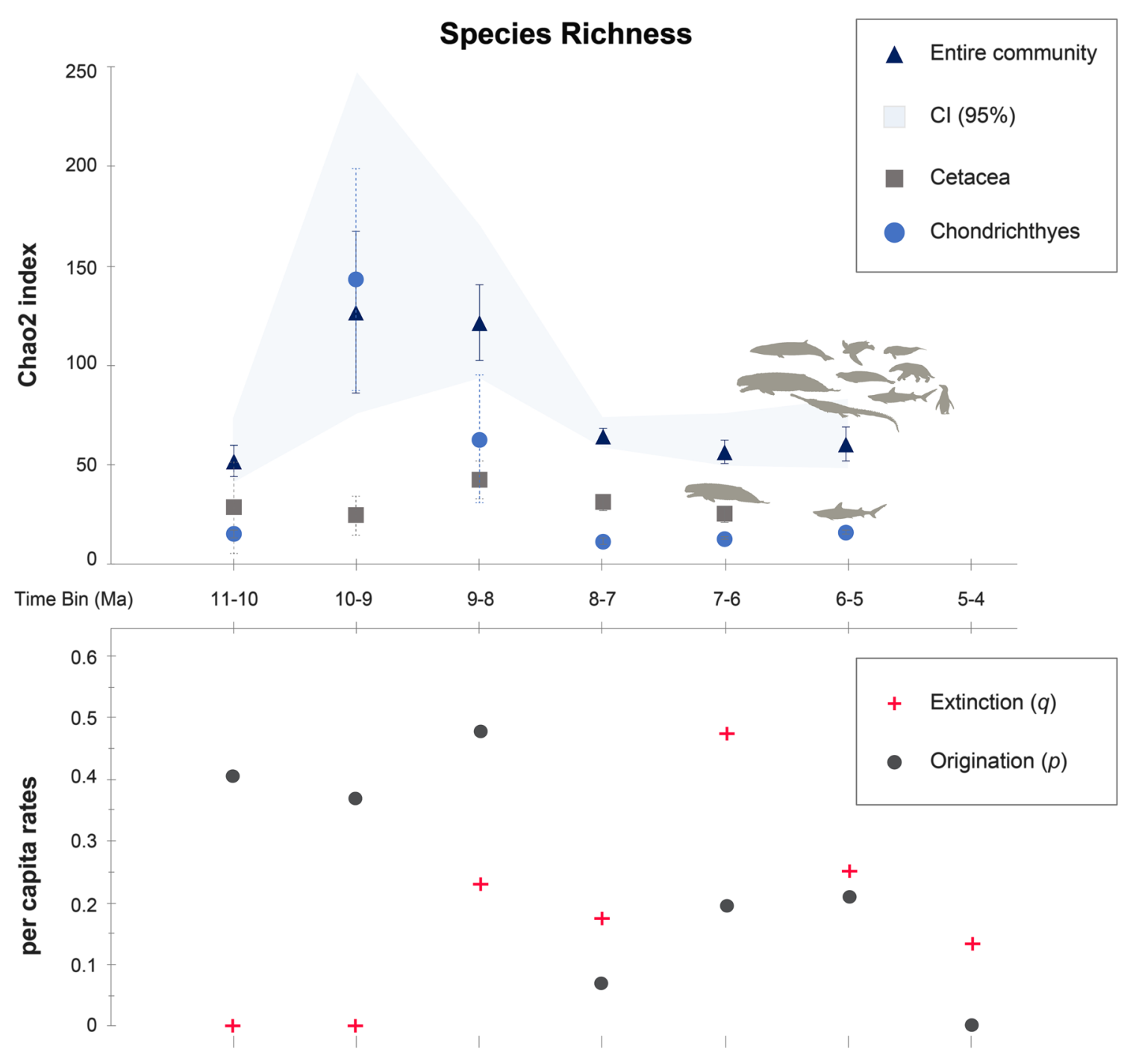

\section{$E(q)$ and $O(p)$ rates}

Fig. 9 Upper box: Chao2 richness index calculated per million-year for all genera present in the fossil assemblage (filled triangles), as well as for the two most abundant phylogenetic groups: cetaceans (filled squares) and chondrichthyans (filled dots). Lower box: Per cap-

and unique environmental conditions and an original evolutionary trajectory at least since the late Miocene. The sole record of sirenians in the EPB occurred at the beginning of this time bin. Shortly thereafter, Thalassocnus was the sole herbivorous mammal within the Pisco ecosystem, possibly indicating a reduction of seagrass beds.

\section{7-4.5 Ma: Diversity decline and the first record of extant odontocete genera}

Crown odontocete subclades from the EPB lost substantial genus richness (from 10 to 3 genera) at $\sim 7-6 \mathrm{Ma}$ (Fig. 6). ita origination (filled dots) versus extinction (crosses) rates estimated per million-year, excluding singletons. Note the strong diversity drop in cetaceans after the $6 \mathrm{Ma}$, as well as the high extinction rate peak observed between 7 and $6 \mathrm{Ma}$

This drop, captured by the Chao2 index (Fig. 9), also occurs in the Ziphiidae, Phocoenidae, and Pontoporiidae clades (Fig. 6). It coincides with the global Messinian diversity decline (Marx et al. 2017), which has been linked to a decrease in ocean primary productivity after a strong reduction in diatom diversity (Marx and Uhen 2010). Sampling bias has been invoked as a possible cause for this diversity reduction (Uhen and Pyenson 2007; Marx et al. 2017). However, our extended synthesis shows a robust decline in some groups of odontocetes in the EPB record (Figs. 9, 10).

As mentioned before, the marked increase in similarity values in the late Miocene-early Pliocene ( 7-4.5 Ma) time 
Table 2 Faunal resemblance index (Simpson Coefficient) among fossil faunas and modern coastal-oceanic taxa dwelling in waters at $13-14^{\circ} \mathrm{S}$ latitude

\begin{tabular}{|c|c|c|c|c|c|}
\hline Simpson coefficient (SC) per time bin & $>10 \mathrm{Ma}$ & $10-7 \mathrm{Ma}$ & $7-4.5 \mathrm{Ma}$ & $2.7-1 \mathrm{Ma}$ & Modern \\
\hline Taxa count & 36 & 57 & 43 & 17 & 59 \\
\hline Taxa count (without Chondrichthyes) & 21 & 38 & 30 & 10 & 41 \\
\hline Minimum/maximum number of shared genera (with chondrichthyes) & $(9) /(9)$ & $(15) /(17)$ & $(16) /(19)$ & $(12) /(14)$ & - \\
\hline $\begin{array}{l}\text { Minimun (SCmin) and maximum (SCmax) value of faunal similarity (with chondry- } \\
\text { chtyes) }\end{array}$ & 25.0 & $26.3-29.8$ & $37.2-44.2$ & $70.6-82.4$ & - \\
\hline Minimum/maximum number of shared genera (without chondrichthyes) & $(1) /(1)$ & $(5) /(7)$ & $(8) /(10)$ & $(7) /(9)$ & - \\
\hline $\begin{array}{l}\text { Minimun (SCmin) and maximum (SCmax) value of faunal similarity (without chondry- } \\
\text { chtyes) }\end{array}$ & 4.8 & $15.8-18.4$ & $26.7-33.3$ & $70.0-90.0$ & - \\
\hline
\end{tabular}

Fossil localities have been clustered based on their chronostratigraphic position as: Miocene older than $10 \mathrm{Ma}(>10 \mathrm{Ma})$, late Miocene ( 10-7 Ma), late Miocene to early Pliocene ( 7-4.5 Ma), and Plio-Pleistocene (2.7-1 Ma). Complete list of fossil genera is available in the Table S2

bin is driven by the first occurrence of extant genera of dwarf sperm whales and true dolphins (Delphinidae) (Fig. 6). In the EPB, the oldest true dolphin remains include four distinct taxa recorded at the Sacaco locality $(\sim 5.8-5.7 \mathrm{Ma}$; Fig. 6). The observed decline in some coastal odontocetes could also be associated with the diversification of true dolphins, which has been documented to occur at 13 and $4 \mathrm{Ma}$ with a peak at 7.5 Ma (e.g., Steeman et al. 2009; Bianucci 2013; Rabosky 2014). Taxa with putative regional and more limited distribution, such as phocid seals, Thalassocnus, and Odobenocetops, arose and became abundant at this time (Fig. 6), suggesting local stability of the coastal-marine environments.

As for the endemic forms, such as the aquatic sloth Thalassocnus, the walrus-like dolphin Odobenocetops, and the gavialoid Piscogavialis, the record shows that they persisted until the last preserved Pisco beds (Figs. 6, 7). These animals are regarded as highly dependent on coastal settings; therefore, any disruption of foreshore habitats by Andean tectonics or reduction of neritic zones after sea-level oscillations (see Pimiento et al. 2017) might have occurred later, during the 4.5-2.7 Ma sedimentary hiatus (Fig. 10).

\section{7-1 Ma: the Caracoles-Pongo fossil record}

After a gap of $1.8 \mathrm{My}$, accumulation and preservation of sediments was reestablished by the late Pliocene (2.7 Ma) with no traces of the endemic forms from the upper Pisco sediments. The existing paleontological data point to a loss of some ecological roles (e.g., marine herbivory practiced by the aquatic sloth Thalassocnus, macroraptorial feeders) and suggest a change in coastal environmental conditions and a shift into a functionally structured community closer to that of the modern HCS (Fig. 10). Top predators of the Caracoles and Pongo formations include delphinid dolphins and a pinniped assemblage consisting of two otariids (eared seals) and a walrus (Fig. 6). Both otariids and the walrus might have dispersed from the northern hemisphere during the middle Pliocene, but the precise time and mode are currently uncertain. Otariids are typically confined to cool waters and coastal upwelling (Deméré et al. 2003), suggesting a cooling of coastal waters were cooler by $2.7 \mathrm{Ma}$.

\section{Paleoecology of the coastal-marine communities during the late Miocene-early Pliocene}

Insights into the structure of the Pisco coastal-marine communities (hereafter referred to as the Pisco ecosystem) are provided by the fossil record of predators, food resources, and their agonistic interactions. This evidence allows for reconstructing putative trophic levels and comparison with modern conditions.

Raptorial sperm whales (e.g., Acrophyseter, Livyatan) were probably the top mammalian predators in the Pisco ecosystem throughout the middle Miocene-early Pliocene, a trophic position now occupied by the killer whale, Orcinus orca (Lambert et al. 2014, 2016). These animals are considered as macroraptorial feeders (i.e., they consume large preys). The largest raptorial sperm whale, Livyatan, would have reached up to $16 \mathrm{~m}$ and preyed upon medium-sized baleen whales (Lambert et al. 2010). Anatomical features supporting these interpretations are based on their large to giant size, massive teeth, presence of buccal maxillary exostoses, robust jaws, and powerful temporal muscles (Lambert et al. 2010, 2014). Yet, bite-marked bones attributed to their active hunting or scavenging behavior have not been found.

Lamniform sharks are expected to occupy a similar trophic level as raptorial sperm whales. In this case, several bones of baleen whales and phocid seals exhibit shark bite marks attributed to the giant Carcharocles megalodon (Collareta et al. 2017a), which is estimated to reach up to $17 \mathrm{~m}$ 


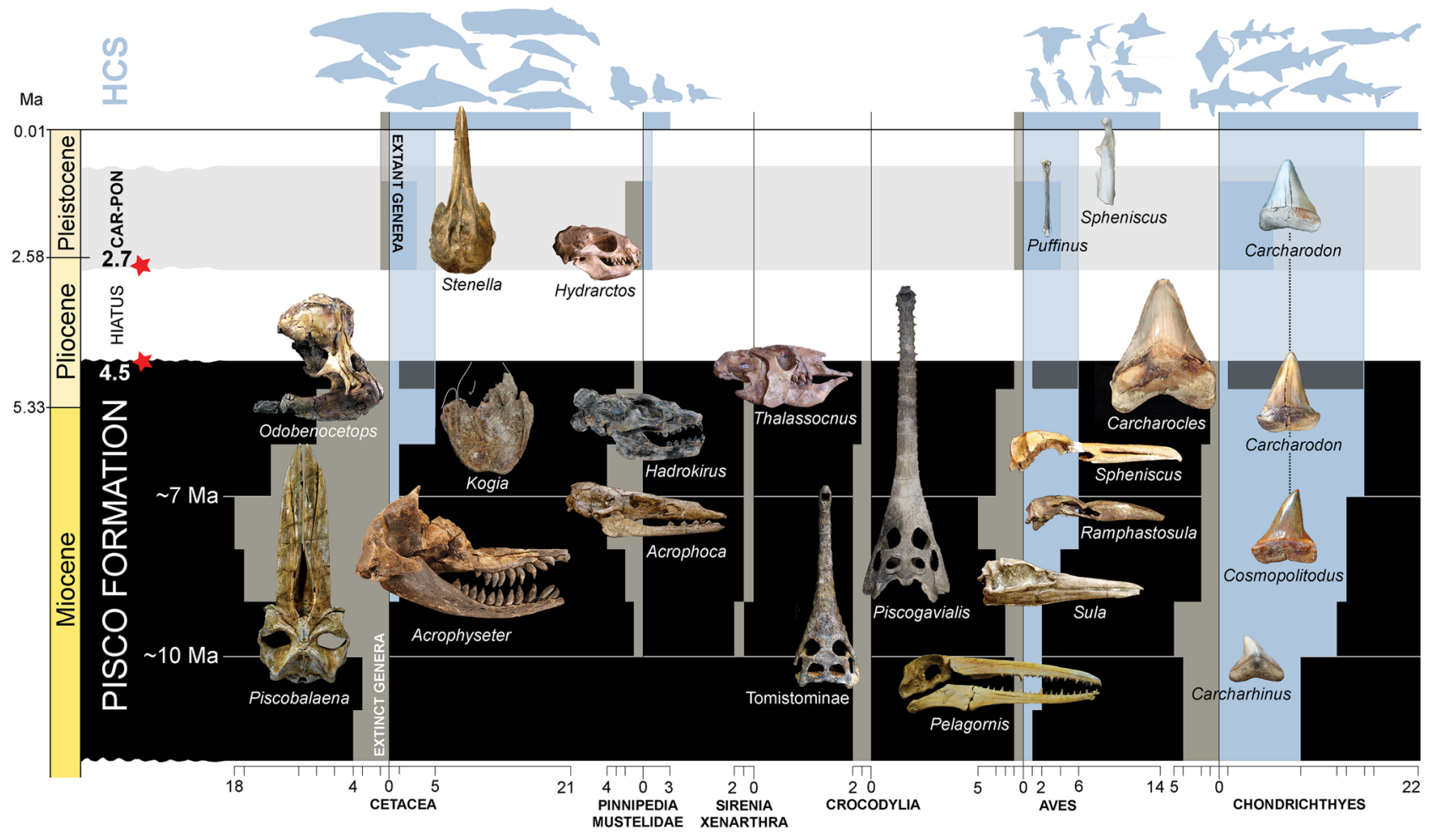

Fig. 10 Summary of main faunal changes experienced in the coastalmarine vertebrate communities from the central Peruvian Margin during the last $10 \mathrm{Ma}$. Red stars indicate new $\mathrm{U} / \mathrm{Pb}$ ages presented

of total body length (Pimiento and Balk, 2015). The white shark Carcharodon and its putative ancestor, Cosmopolitodus, are probably ecological analogs of Carcharocles, but of much smaller size at adulthood (5-7 m; Shimada 2002, 2019). Similar shark tooth marks are preserved in limb bones of the aquatic sloth Thalassocnus, indicating that large sharks also fed upon this marine sloth in coastal areas. However, establishing an indisputable perpetrator is especially difficult, since serrated teeth (e.g., Carcharocles, Carcharodon) can inflict both smooth and serrated marks (see Cortés et al. 2019). As commonly reported for the extant white shark, the Mio-Pliocene Carcharodon also scavenged on whale carcasses as suggested by a tooth embedded within the jawbone of a baleen whale found in the Sud-Sacaco (west) locality (Ehret et al. 2009). Crocodylians from the Pisco ecosystem were not top predators since both taxa bear long and slender snout, linked to the capture of rapid and small prey (e.g., fishes; Salas-Gismondi et al. 2019).

Up to four phocid seal species of distinct body size and snout shape coexisted (at SAS and SAO; Muizon and DeVries 1985). Highly diverse communities are strongly linked to coastal upwellings near continental margins (Deméré et al. 2003), while different snout and tooth shapes might represent a variety of diet preferences. Acrophoca is a large, idiosyncratic seal with a long and slender snout in this work. Grey bars indicate taxonomic richness (at genus level) of fossil groups, and blue bars taxonomic richness (at genus level) of extant groups

(longirostry) and an elongated neck and body (Muizon 1981). Longirostry and precise tooth interlocking suggests a pierce-based feeding strategy suitable for foraging on fishes, cuttlefishes, and octopuses (Muizon 1981; Berta et al. 2018). Hadrokirus bears the most robust dentition among phocid seals. Since this feature is coupled with a powerful neck and masticatory apparatus, durophagy (i.e., a diet based on hard food, such as crabs, lobsters, sea urchins) or carnivory of higher level (penguins) is expected (Amson and Muizon 2013). As for Piscophoca, similarities with the monk seal Monachus suggest a comparable diet, including fishes, squids, and hard-shelled invertebrates (Gilmartin and Forcada 2009). Australophoca, with an estimated body length of one meter, is smaller than any living pinniped (Valenzuela-Toro et al. 2015). Quantitative analyses on the feeding anatomy of this phocid seal community are crucial to test the aforementioned assessments.

Marine herbivores are absent in the modern HCS, but Thalassocnus was most likely a common aquatic herbivorous mammal during the late Miocene-early Pliocene (Muizon and McDonald 1995; McDonald and Muizon 2002; Muizon et al. 2004a, b). Thalassocnus was a bottom walker of protected, shallow waters which mainly fed upon rhizomes of seagrasses (Muizon et al. 2004b; Amson et al. 2015). Thalassocnus feeding anatomy suggests that meadows of 
seagrasses were relatively common in the past. The record from the Pisco Formation is silent in this matter; however, seagrass leaves (Heterozostera) have been reported from Pliocene mudstones located nearby the Nazca area (Hacienda Tunga; Phillips et al. 1996). Nowadays, a single species of seagrasses, Heterozostera chilensis, inhabits the southeastern Pacific, and it is disjunctively present in a couple of bays in central Chile (Kuo 2005; Short et al. 2007). Such confined distribution is attributed to the high-energy exposure of those coasts, which prevents a uniform expansion of the seagrass (Kuo 2005). Since Thalassocnus fossils have been recovered from the youngest deposits of the Pisco Formation, protected, shallow water environments with extensive meadows might have persisted up to $4.5 \mathrm{Ma}$ at the Sacaco sub-basin.

The fossil record of the main guano-producer seabirds (Phalacrocorax, Sula, and Spheniscus) is indicative of large populations since the late Miocene (Urbina and Stucchi 2005; Stucchi 2007; Stucchi et al. 2016). This assemblage is present in the highly productive upwelling systems of the southern hemisphere (Benguela, Humboldt) and suggests similarities with the modern HCS conditions in terms of food resources (Chavez-Hoffmeister et al. 2014). In the HCS, these genera mainly feed upon the pelagic Peruvian anchovy Engaulis rigens (Thiel et al. 2007). Extinct species of Spheniscus (S. muizoni, S. urbinai, S, megaramphus) and Sula (S. magna, S. figueroae, S. brandi, $S$. aff. variegata; $S$. sulita) might have had a diet similar to their modern counterparts, but higher species richness and body size disparity in fossil forms might reflect a wider range of prey items (e.g., Stucchi 2002; Acosta-Hospitaleche et al. 2011; Stucchi et al. 2016; Chavez-Hoffmeister, 2020).

Direct evidence documenting the trophic relationships in the Pisco ecosystem is provided by some rare cases of agonistic interactions recorded as trace fossils. A beaked whale specimen of Messapicetus from Cerro Colorado (MUSM 2252) had numerous skeletons and scales of the clupeid fish Sardinops (sardine) preserved within the chest region and around the head (Lambert et al. 2015). Dermal and bony remains of Sardinops interpreted as forestomach content were also found between the posterior ribs of a small Piscobalaena-like baleen whale (Collareta et al. 2015). Additionally, a partial skeleton of a juvenile individual of the lamniform shark Cosmopolitodus preserved opercles and large scales typical of Sardinops as well, probably belonging to the extant Pacific pilchard S. sagax (Collareta et al. 2017b). These findings suggest that the pilchard was an abundant resource, even for predators with dissimilar feeding anatomy and strategies. Sardine remains are also identified across the Sacaco sub-basin up to the early Pliocene (Muizon and DeVries, 1985), indicating that this fish was likely an important link in the food chain. In the highly productive modern HCS, the dominant schooling fish is the pelagic Peruvian anchovy Engraulis rigens (Tarazona et al. 2003). However, alternations in the abundance between Engraulis and Sardinops occur naturally by environmental changes, in which the biomass of the sardines (and other fishes) rises and prevails during warm and oxygenated El Niño conditions $\left(3-8{ }^{\circ} \mathrm{C}\right.$ warm anomalies; DeVries and Pearcy, 1982; Deméré et al. 2003; Gutiérrez et al. 2012). The presence of Sardinops in the fossil record during the early Pliocene is consistent with the evidence of El Niño-like conditions in the Pacific during that time (Wara et al. 2005; Dekens et al. 2007; Brierley et al. 2009).

\section{Conclusions}

Since the pioneering work of Muizon and DeVries (1985), the EPB has yielded numerous paleontological discoveries that contribute to the understanding of the evolution of different clades. In this work, we revisited the Mio-Pliocene chronostratigraphy of the Sacaco sub-basin, reviewed the vertebrate paleontological record, and addressed biodiversity and ecological changes over the last $10 \mathrm{My}$ in an integrated geological and environmental context. Main findings are summarized as follows:

1. Radiometric results indicate that the last known preserved Pisco sediments from the Sacaco sub-basin are dated as 4.5 (Quebrada Caracoles) (Table 1), whilst the succession from the Sacaco locality was accumulated at 5.8-5.7 Ma, as indicated by Ehret et al. (2012). The Pisco Formation at the Sacaco sub-basin thus spans from $\sim 10$ to $4.5 \mathrm{Ma}$ (Fig. 2).

2. The base of the late Pliocene Caracoles Formation was dated at 2.7 My, this unit was accumulated under more proximal settings (shoreface) than the underlying Pisco Formation. The contact between these formations is characterized by an erosive surface with subtle changes in dip angles, evidencing the presence of an angular unconformity (Fig. 3b). The minimum time gap represented by this hiatus is of $1.8 \mathrm{My}$. We associate this unconformity with a Pliocene phase of surficial uplift, which would have led to the cessation of sedimentation, uplifting, and erosion from 4.5 to $2.7 \mathrm{Ma}$.

3. Different communities have existed over the last $10 \mathrm{My}$ on the Peruvian margin. Faunal changes occur across various phylogenetic groups but are especially observed within marine mammals (odontocete cetaceans, and pinnipeds). The late Miocene assemblages ( $>10 \mathrm{Ma}$ and $\sim 10-7 \mathrm{Ma}$ ) were dominated by several cetacean clades (i.e., ziphiids, phocoenids, pontoporiids) that show a marked decline at $\sim \mathrm{Ma}$. An early faunal change among odontocetes is observed between 7 and $6 \mathrm{Ma}$. Besides seabirds, the first record attributable to con- 
spicuous representatives of the modern HCS community (i.e., the delphinid dolphins Stenella, Delphinus, Lagenorhynchus, and the pygmy sperm whale Kogia) appear in the record by $\sim 7$ Ma. Phocid seals and endemic taxa (e.g., the sloth Thalassocnus, the walrus-like dolphin Odobenocetops, and the crocodylian Piscogavialis) prevail and survive until the last known Pisco deposits. The time of the extinction of these inhabitants from the Pisco ecosystem occurred between 4.5 and $2.7 \mathrm{Ma}$ (Fig. 10). A new community, much closer to the modern one is observed in the Plio-Pleistocene (2.7-1 Ma), although some key taxa (e.g., Megaptera, Otaria) of the modern HCS ecosystems are still absent (Figs. 6, 7). The substantial ecosystem reorganization that occurred during the 4.5-2.7 Ma sedimentary hiatus was likely linked to a coastal geomorphological transformation due to tectonic uplift.

4. The abundant diatom-rich beds, schooling fishes (Sardinops) as well as the trophic chains supporting giant cetaceans are indicators of continuous high upwelling related productivity during Mio-Pliocene times. Except for transient oxygen-depleted events, the sedimentological record from the Pisco Formation at the Sacaco subbasin does not show evidence of the strong perennial low-oxygen zone (above $100 \mathrm{mbsl}$ ) which characterizes the modern HCS.

Supplementary Information The online version contains supplementary material available at https://doi.org/10.1007/s00531-021-02003-1.

Acknowledgements This research was supported by the Peruvian Fondo Nacional de Desarrollo Científico, Tecnológico y de Innovación Tecnológica (FONDECYT) through the Programa de incorporación de investigadores (Grant $\mathrm{N}^{\circ}$ E038-2019-02-FONDECYT-Banco Mundial) and the MAGNET program (Contract $\mathrm{N}^{\circ} 07-2017-\mathrm{FONDECYT).}$ Funding was also available through the Consejo Nacional de Ciencia, Tecnología e Innovación Tecnológica (CONCYTEC) -FONDECYT research grants 105-2018 and 104-2018 awarded to DO and RS-G, respectively. We especially thank R. Varas (UPCH, Peru), L. Pairazamán (UNI, Peru) and R. Berrospi (UNI, Peru) for logistical assistance during the second field campaign. PERUPETRO S.A. and Ysabel Calderón are thanked for providing access to seismic data. This manuscript greatly benefited from comments by J. Macharé, A. Collareta, R. Esperante, and C. DiCelma.

Author contributions Conceptualization and design of study: DO, RS-G, MC. Acquisition of data: DO, RS-G, TJD, PB, CM, AA, AB-E, DAF, KQ, JC, DG, AP, MC. Analysis and/or interpretation of data: DO, RS-G, TJD, CM, AA, AB-E, KQ, MC. Drafting the manuscript: DO, RS-G, MC. Critical review and approval of the final version of the manuscript: DO, RS-G, TJD, PB, CM, AA, AB-E, DAF, KQ, JC, DG, AP, MC. Funding acquisition: DO, RS-G, DG, JC.

Funding This research was supported by the Peruvian Fondo Nacional de Desarrollo Científico, Tecnológico y de Innovación Tecnológica (FONDECYT) through the Programa de incorporación de investigadores (Grant N ${ }^{\circ}$ E038-2019-02-FONDECYT-Banco Mundial) and the
MAGNET program (Contract N ${ }^{\circ}$ 07-2017-FONDECYT). Funding was also available through the Consejo Nacional de Ciencia, Tecnología e Innovación Tecnológica (CONCYTEC) -FONDECYT research grants 105-2018 and 104-2018 awarded to DO and RS-G, respectively.

Data availability Not applicable.

Code availability Not applicable.

\section{Declarations}

Conflict of interest Not applicable.

Open Access This article is licensed under a Creative Commons Attribution 4.0 International License, which permits use, sharing, adaptation, distribution and reproduction in any medium or format, as long as you give appropriate credit to the original author(s) and the source, provide a link to the Creative Commons licence, and indicate if changes were made. The images or other third party material in this article are included in the article's Creative Commons licence, unless indicated otherwise in a credit line to the material. If material is not included in the article's Creative Commons licence and your intended use is not permitted by statutory regulation or exceeds the permitted use, you will need to obtain permission directly from the copyright holder. To view a copy of this licence, visit http://creativecommons.org/licenses/by/4.0/.

\section{References}

Abrantes F, Lopes C, Mix A, Pisias N (2007) Diatoms in Southeast Pacific surface sediments reflect environmental properties. Quatern Sci Rev 26(1-2):155-169

Acosta-Hospitaleche C, Altamirano-Sierra A, Stucchi M (2011) Variacionesmorfológicas del tarsometatarso de los pingüinos (Aves, Sphenisciformes) de la secuenciaestratigráfica de la FormaciónPisco (Mioceno-Plioceno), Perú. Rev Mexicana de CienciasGeol 28:290-300

Adams GI (1906) Caudal, procedencia y distribución de aguas de los Dptos. de Lima e Ica. Bol Cuerpo de Ingenieros 5:367-379

Adams GI (1908) An outline review of the Geology of Peru, Annual Report. Smithosonian Institution, Washington, pp 385-430

Alarcón P, Anzoleaga R, Gonzáles E, Bianchi C, Fuente, (2005) EstilosEstructurales y Evolución de las CuencasCostafuera del Perú y supotencialHidrocarburifero. INGEPET, Lima, p 41

Altamirano-Sierra AJ (2013) Primer registro de pelícano (Aves: Pelecanidae) para el Miocenotardío de la formaciónPiscoPerú. Bulletin de l'InstitutFrançaisd'étudesAndines 42(1):1052

Amiot R, Göhlich UB, Lecuyer C, Muizon C, Cappetta H, Fourel F, Héran M-A, Martineau F (2008) Oxygen isotope compositions of phosphate from Middle Miocene-Early Pliocene marine vertebrates of Peru. PalaeogeogrPalaeoclimatolPalaeoecol 264(12):85-92. https://doi.org/10.1016/j.palaeo.2008.04.001

Amson E, Muizon CD (2013) A new durophagousphocid (Mammalia: Carnivora) from the late Neogene of Peru and considerations on monachine seals phylogeny. J SystPaleontol 12(5):523-548. https ://doi.org/10.1080/14772019.2013.799610

Amson E, Muizon CD, Domning DP, Argot C, De Buffrénil V (2015) Bone histology as a clue for resolving the puzzle of a dugong rib in the Pisco Formation, Peru. J Vertebr Paleontol 35(3):e922981. https://doi.org/10.1080/02724634.2014.922981

Arntz WE, Gallardo VA, Gutiérrez D, Isla E, Levin LA, Mendo J, Neira C, Rowe GT, Tarazona J, Wolff M (2006) El Niño and similar perturbation effects on the benthos of the Humboldt, 
California, and Benguela Current upwelling ecosystems. AdvGeosci 6:243-265

Ayón P, Criales-Hernandez MI, Schwamborn R, Hirche H-J (2008) Zooplankton research off Peru: a review. Prog Oceanogr 79(2-4):238-255

Balarezo R, Samame-Boggio M, Morales-Arnao B (1980) Synopsis Explicativa del MapaGeologico del Departamento de lca. InstitutoGeologicoMinero y Metalurgica, Lima, pp 1-27

Barnes LG, Godfrey SJ, Bohaska DJ (2006) Kentriodontid dolphins from the Chesapeake Group: indicators of the evolutionary diversity of dolphins during Miocene time, the geology and paleontology of calvert cliffs, A Symposium of the Calvert Marine Museum The Ecphora Miscellaneous Publications, pp 22-23

Benites-Palomino A, Velez-Juarbe J, Salas-Gismondi R, Urbina M (2020) Scaphokogiatotajpe, sp. nov., a new bulky-faced pygmy sperm whale (Kogiidae) from the late Miocene of Peru. J VertebrPaleontol. https://doi.org/10.1080/02724634.2019.1728538

Benites-Palomino A, Velez-Juarbe J, Collareta A, Ochoa D, Altamirano A, Carré M, Laime M, Urbina M, Salas-Gismondi R (2021) Nasal compartmentalization in Kogiidae (Cetacea, Physeteroidea): insights from a new late Miocene dwarf sperm whale from the Pisco Formation. Pap Palaeontol. https://doi. org/10.1002/spp2.135

Berta A, Churchill M, Boessenecker RW (2018) The origin and evolutionary biology of pinnipeds: seals, sea lions, and walruses. Annu Rev Earth Planet Sci 46:203-228. https://doi.org/10.1146/annur ev-earth-082517-010009

Bianucci G, Sorbi S, Suárez ME, Landini W (2006) The southernmost sirenian record in the eastern Pacific Ocean, from the Late Miocene of Chile. CR Palevol 5(8):945-952

Bianucci G, Lambert O, Salas-Gismondi R, Tejada J, Pujos F, Urbina M, Antoine P-O (2013) A Miocene relative of the Ganges river dolphin (Odontoceti, Platanistidae) from the Amazonian Basin. J VertebrPaleontol 33(3):741-745. https://doi.org/10.1080/02724 634.2013.734888

Bianucci G, Di Celma C, Collareta A, Landini W, Post K, Tinelli C, Muizon CD, Bosio G, Gariboldi K, Gioncada A (2016a) Fossil marine vertebrates of Cerro Los Quesos: distribution of cetaceans, seals, crocodiles, seabirds, sharks, and bony fish in a late Miocene locality of the Pisco Basin, Peru. J Maps 12(5):10371046. https://doi.org/10.1080/17445647.2015.1115785

Bianucci G, Di Celma C, Landini W, Post K, Tinelli C, Muizon CS, Gariboldi K, Malinverno E, Cantalamessa G, Gioncada A (2016b) Distribution of fossil marine vertebrates in Cerro Colorado, the type locality of the giant raptorial sperm whale Livyatan melvillei (Miocene, Pisco Formation, Peru). J Maps 12(3):543-557. https://doi.org/10.1080/17445647.2015.1048315

Bianucci G, Collareta A, Bosio G, Landini W, Gariboldi K, Gioncada A, Lambert O, Malinverno E, Muizon CD, Varas-Malca R, Villa I, Coletti G, Urbina M, Di Celma C (2018) Taphonomy and palaeoecology of the lower Miocene marine vertebrate assemblage of Ullujaya (Chilcatay Formation, East Pisco Basin, southern Peru). Palaeogeogr Palaeoclimatol Palaeoecology 511:256-279. https://doi.org/10.1016/j.palaeo.2018.08.013

Bianucci G, Muizon CD, Urbina M, Lambert O (2020) Extensive Diversity and Disparity of the Early Miocene Platanistoids (Cetacea, Odontoceti) in the Southeastern Pacific (Chilcatay Formation, Peru). Life 10(3):27. https://doi.org/10.3390/life10030027

Boessenecker RW, Perry FA, Schmitt JG (2014) Comparative taphonomy, taphofacies, and bonebeds of the Mio-Pliocene Purisima Formation, Central California: strong physical control on marine vertebrate preservation in shallow marine settings. PLoS ONE 9(3):e91419. https://doi.org/10.1371/journal.pone.0091419

Boessenecker RW, Fraser D, Churchill M, Geisler JH (2017) A toothless dwarf dolphin (Odontoceti: Xenorophidae) points to explosive feeding diversification of modern whales (Neoceti).
Proc R Soc B 284(1861):20170531. https://doi.org/10.1098/ rspb.2017.0531

Bosio G, Malinverno E, Villa I, Di Celma C, Gariboldi K, Gioncada A, Barberini V, Urbina M, Bianucci G (2019) Tephrochronology and chronostratigraphy of the Miocene Chilcatay and Pisco formations (East Pisco Basin, Peru). NewslStratigr 53(2):213-247. https://doi.org/10.1127/NOS\%2F2019\%2F0525

Bosio G, Malinverno E, Collareta A, Di Celma C, Gioncada A, Parente M, Berra F, Marx FG, Vertino A, Urbina M (2020) Strontium Isotope Stratigraphy and the thermophilic fossil fauna from the middle Miocene of the East Pisco Basin (Peru). J S Am Earth Sci 97:102399. https://doi.org/10.1016/j.jsames.2019.102399

Bouetel V, Muizon CD (2006) The anatomy and relationships of Piscobalaena nana (Cetacea, Mysticeti), a Cetotheriidaess from the early Pliocene of Peru. Geodiversitas 28(2):319-395

Brand LR, Esperante R, Chadwick AV, Porras OP, Alomía M (2004) Fossil whale preservation implies high diatom accumulation rate in the Miocene-Pliocene Pisco Formation of Peru. Geology 32(2):165-168. https://doi.org/10.1130/G20079.1

Brand L, Urbina M, Chadwick A, DeVries TJ, Esperante R (2011) A high resolution stratigraphic framework for the remarkable fossil cetacean assemblage of the Miocene/Pliocene Pisco Formation, Peru. J S Am Earth Sci 31(4):414-425. https://doi.org/10.1016/j. jsames.2011.02.015

Brierley C, Fedorov A, Liu Z, Herbert TD, Lawrence KT, LaRiviere JP (2009) Greatly expanded tropical warm pool and weakened Hadley circulation in the early Pliocene. Science 323(5922):17141718. https://doi.org/10.1126/science. 1167625

Caldas J (1978) Geología de los Cuadrángulos de San Juan. Acarí y Yauca (Hojas 31-m, 31-n 32-n), Ingemmet, Lima, Peru

Canto J, Salas-Gismondi R, Cozzuol M, Yáñez J (2008) The aquatic sloth Thalassocnus (Mammalia, Xenarthra) from the late Miocene of north-central Chile: biogeographic and ecological implications. J VertebrPaleontol 28(3):918-922. https://doi. org/10.1671/0272-4634(2008)28[918:TASTMX]2.0.CO;2

Cardich J, Sifeddine A, Salvatteci R, Romero D, Briceño F, Graco MI, Anculle T, Almeida C, Gutiérrez Aguilar DA (2019) Multidecadal changes in marine subsurface oxygenation off central Peru during the last ca 170 years. Front Mar Sci 6:270. https://doi. org/10.3389/fmars.2019.00270

Chavez M, Stucchi M, Urbina M (2007) El registro de Pelagornithidae (Aves: Pelecaniformes) y la avifauna neógena del Pacíficosudeste. Bull de l'InstitutFrançaisd'EtudesAndines 36(2):175-197

Chavez-Hoffmeister M (2020) Bill disparity and feeding strategies among fossil and modern penguins. Paleobiology. https://doi. org/10.1017/pab.2020.10

Chavez-Hoffmeister M, Briceño JDC, Nielsen SN (2014) The evolution of seabirds in the Humboldt Current: New clues from the Pliocene of central Chile. PLoS ONE. https://doi.org/10.1371/ journal.pone.0090043

Chiu CH, Wang YT, Walther BA, Chao A (2014) An improved nonparametric lower bound of species richness via a modified GoodTuring frequency formula. Biometrics 70(3):671-682. https:// doi.org/10.1111/biom. 12200

Clarke JA, Ksepka DT, Salas-Gismondi R, Altamirano AJ, Shawkey MD, D’Alba L, Vinther J, DeVries TJ, Baby P (2010) Fossil evidence for evolution of the shape and color of penguin feathers. Science 330(6006):954-957. https://doi.org/10.1126/scien ce. 1193604

Colbert EH (1944) A new fossil whale from the Miocene of Peru. American Museum of Natural History, Lima, p 32

Collareta A, Landini W, Lambert O, Post K, Tinelli C, Di Celma C, Panetta D, Tripodi M, Salvadori PA, Caramella D (2015) Piscivory in a Miocene Cetotheriidae of Peru: first record of fossilized stomach content for an extinct baleen-bearing whale. Sci Nat 102(11-12):70. https://doi.org/10.1007/s00114-015-1319-y 
Collareta A, Lambert O, Muizon CD, Urbina M, Bianucci G (2017a) Koristocetus pescei gen. et sp. nov., a diminutive sperm whale (Cetacea: Odontoceti: Kogiidae) from the late Miocene of Peru. Foss Rec 20:259-278. https://doi.org/10.5194/fr-20-259-2017

Collareta A, Landini W, ChacaltanaBudiel CA, Valdivia Vera W, Altamirano Sierra AJ, Urbina Schmitt M, Bianucci G (2017b) A well preserved skeleton of the fossil shark Cosmopolitodus hastalis from the late Miocene of Peru, featuring fish remains as fossilized stomach contents. Riv Ital Paleontol Stratigr 123:11-22

Cortés D, De Gracia C, Carrillo-Briceño JD, Aguirre-Fernández G, Jaramillo C, Benites-Palomino A, Atencio-Araúz JE (2019) Shark-cetacean trophic interactions during the late Pliocene in the Central Eastern Pacific (Panama). Palaeontol Electron 22(2):1-13. https://doi.org/10.26879/953

Couch R, Whitsett R (1981) Structures of the Nazca Ridge and the continental shelf and slope of southern Peru. GeolSoc Am 154:569-584

Croft DA (2007) The middle Miocene (Laventan) Quebrada Honda fauna, southern Bolivia and a description of its notoungulates. Palaeontology 50(1):277-303. https://doi.org/10.111 $1 / j .1475-4983.2006 .00610 . x$

Davila D (1989) Neogene Stratigraphy of the Pisco Basin and VolcanicTectonic Events. INGEMMET, Lima

De Los Arcos S, Partarrieu D, Carrillo-Briceño J, Amson E (2017) The Southernmost Occurrence of the Aquatic Sloth Thalassocnus (Mammalia, Tardigrada) in Two New Pliocene Localities in Chile. Ameghiniana 54(4):351-369. https://doi.org/10.5710/ AMGH.29.12.2016.3004

Dekens PS, Ravelo AC, McCarthy MD (2007) Warm upwelling regions in the Pliocene warm period. Paleoceanography. https://doi. org/10.1029/2006pa001394

Deméré TA, Berta A, Adam P (2003) Chapter 3: pinnipedimorph evolutionary biogeography. Bull Am Mus Natl Hist 279:32-76

DeVries TJ (2020) Lithostratigraphy and biostratigraphy of pliocene and pleistocene marine deposits and age of the highest marine terrace from the sacaco basin and its environs (southern Peru). Boletín de la Sociedad Geológica del Perú 114:20-48

DeVries TJ, Frassinetti D (2003) Range extensions and biogeographic implications of Chilean Neogene mollusks found in Peru. Boletín del MuseoNacional de Historia Natural de Chile 52:119-135

DeVries TJ, Jud N (2018) Lithofacies patterns and paleogeography of the Miocene Chilcatay and lower Pisco depositional sequences (East Pisco Basin, Peru). Boletín de la SociedadGeológica del Perú, volumenjubilar 8:124-167

DeVries TJ, Pearcy WG (1982) Fish debris in sediments of the upwelling zone off central Peru: a late Quaternary record. Deep Sea Res Part A 29(1):87-109. https://doi.org/10.1016/01980149(82)90063-2

DeVries TJ, Wells LE (1990) Thermally-anomalous Holocene molluscan assemblages from coastal Peru: evidence for paleographic, not climatic change. PalaeogeogrPalaeoclimatolPalaeoecol 81(1-2):11-32. https://doi.org/10.1016/0031-0182(90)90037-8

Di Celma C, Malinverno E, Cantalamessa G, Gioncada A, Bosio G, Villa IM, Gariboldi K, Rustichelli A, Pierantoni P, Landini W (2016a) Stratigraphic framework of the late Miocene Pisco Formation at Cerro Los Quesos (Ica Desert, Peru). J Maps 12(5):1020-1028. https://doi.org/10.1080/17445647.2015.11157 83

Di Celma C, Malinverno E, Gariboldi K, Gioncada A, Rustichelli A, Pierantoni P, Landini W, Bosio G, Tinelli C, Bianucci G (2016b) Stratigraphic framework of the late Miocene to Pliocene Pisco Formation at Cerro Colorado (Ica Desert, Peru). J Maps 12(3):515-529. https://doi.org/10.1080/17445647.2015.1047906

Di Celma C, Malinverno E, Bosio G, Collareta A, Gariboldi K, Gioncada A, Molli G, Basso D, Varas-Malca RM, Pierantoni PP (2017) Sequence stratigraphy and paleontology of the Upper
Miocene Pisco Formation along the western side of the lower Ica Valley (Ica Desert, Peru). Riv Ital Paleontol Stratigr 123:255273. https://doi.org/10.13130/2039-4942/8373

Di Celma C, Malinverno E, Collareta A, Bosio G, Gariboldi K, Lambert O, Landini W, Pierantoni P, Gioncada A, Villa I (2018) Facies analysis, stratigraphy and marine vertebrate assemblage of the lower Miocene Chilcatay Formation at Ullujaya (Pisco basin, Peru). J Maps 14(2):257-268. https://doi.org/10.1080/17445 647.2018.1456490

Domning DP (2001) The earliest known fully quadrupedal sirenian. Nature 413(6856):625-627

Domning DP, Aguilera OA (2008) Fossil Sirenia of the West Atlantic and Caribbean region. VIII. Nanosiren garciae, gen. et sp. nov. and Nanosiren sanchezi, sp. nov. J Vertebr Paleontol 28(2):479500. https://doi.org/10.1671/0272-4634(2008)28[479:FSOTW A]2.0.CO;2

Dunbar R, Baker P (1988) Cenozoic geology of the Pisco basin: Field Guidebook Regional IGCP. Genesis of Cenozoic Phophorites and Associated Organic-rich Sediments: Peruvian Continental Margin. IGCP, Lima

Dunbar RB, Marty RC, Baker PA (1990) Cenozoic marine sedimentation in the Sechura and Pisco basins, Peru. PalaeogeogrPalaeoclimatolPalaeoecol 77(3):235-261. https://doi.org/10.1016/00310182(90)90179-B

Ehret DJ, MacFadden BJ, Salas-Gismondi R (2009) Caught in the act: trophic interactions between a 4-million-year-old white shark (Carcharodon) and mysticete whale from Peru. Palaios 24(5):329-333. https://doi.org/10.2110/palo.2008.p08-077r

Ehret DJ, Macfadden BJ, Jones DS, DeVries TJ, Foster DA, Salas-Gismondi R (2012) Origin of the white shark Carcharodon (Lamniformes: Lamnidae) based on recalibration of the Upper Neogene Pisco Formation of Peru. Palaeontology 55(6):1139-1153. https ://doi.org/10.1111/j.1475-4983.2012.01201.x

Esperante R, Brand LR, Nick KE, Poma O, Urbina M (2008) Exceptional occurrence of fossil baleen in shallow marine sediments of the Neogene Pisco Formation, Southern Peru. PalaeogeogrPalaeoclimatolPalaeoecol 257(3):344-360

Esperante R, Brand LR, Chadwick AV, Poma O (2015) Taphonomy and paleoenvironmental conditions of deposition of fossil whales in the diatomaceous sediments of the Miocene/Pliocene Pisco Formation, southern Peru. A new fossil-lagerstätte. PalaeogeogrPalaeoclimatolPalaeoecol 417:337-370. https://doi.org/10.1016/j. palaeo.2014.09.029

Espurt N, Baby P, Brusset S, Roddaz M, Hermoza W, Regard V, Antoine P-O, Salas-Gismondi R, Bolanos R (2007) How does the Nazca Ridge subduction influence the modern Amazonian foreland basin? Geology 35(6):515-518. https://doi.org/10.1130/ G24631Y.1

Foote M (2000) Deep time: paleobiology's perspective. Paleobiology 26(4):74-102

Gariboldi K, Gioncada A, Bosio G, Malinverno E, Di Celma C, Tinelli C, Cantalamessa G, Landini W, Urbina M, Bianucci G (2015) The dolomite nodules enclosing fossil marine vertebrates in the East Pisco Basin, Peru: field and petrographic insights into the Lagerstätte formation. PalaeogeogrPalaeoclimatolPalaeoecol 438:81-95. https://doi.org/10.1016/j.palaeo.2015.07.047

Gariboldi K, Bosio G, Malinverno E, Gioncada A, Di Celma C, Villa IM, Urbina M, Bianucci G (2017) Biostratigraphy, geochronology and sedimentation rates of the upper Miocene Pisco Formation at two important marine vertebrate fossil-bearing sites of southern Peru. NewslStratigr 50(4):417-444. https://doi. org/10.1127/nos/2017/0345

Gilmartin WG, Forcada J (2009) Monk Seals: Monachusmonachus, $M$ tropicalis, and $M$ schauinslandi. Encyclopedia of marine mammals. Elsevier, Amsterdam, pp 741-744 
Gioncada A, Petrini R, Bosio G, Gariboldi K, Collareta A, Malinverno E, Bonaccorsi E, Di Celma C, Pasero M, Urbina M (2018) Insights into the diagenetic environment of fossil marine vertebrates of the Pisco Formation (late Miocene, Peru) from mineralogical and Sr-isotope data. J S Am Earth Sci 81:141-152

Grigg G, Kirshner D (2016) Long submergences by crocodylians and their physiological support: a working hypothesis. Crocodiles 189:542

Gutiérrez D, Sifeddine A, Reyss J, Vargas G, Velazco F, Salvatteci R, Ferreira V, Ortlieb L, Field D, Baumgartner TR (2006) Anoxic sediments off Central Peru record interannual to multidecadal changes of climate and upwelling ecosystem during the last two centuries. AdvGeosci 6:119-125. https://doi.org/10.5194/adgeo $-6-119-2006$

Gutiérrez D, Sifeddine A, Field D, Ortlieb L, Vargas G, Chavez FP, Velazco F, Ferreira V, Tapia P, Salvatteci R (2009) Rapid reorganization in ocean biogeochemistry off Peru towards the end of the Little Ice Age. Biogeosciences 6:835-848. https://doi. org/10.5194/bg-6-835-2009

Gutiérrez M, Castillo R, Segura M, Peraltilla S, Flores M (2012) Trends in spatio-temporal distribution of Peruvian anchovy and other small pelagic fish biomass from 1966-2009 v. Latin Am J Aquat Res 40(3):633-648. https://doi.org/10.3856/vol40-issue 3-fulltext-12

Gutstein CS, Cozzuol MA, Vargas AO, Suárez ME, Schultz CL, Rubilar-Rogers D (2009) Patterns of skull variation of Brachydelphis (Cetacea, Odontoceti) from the Neogene of the Southeastern Pacific. J Mammal 90(2):504-519. https://doi. org/10.1644/07-MAMM-A-081.1

Hampel A (2002) The migration history of the Nazca Ridge along the Peruvian active margin: a re-evaluation. Earth Planet Sci Lett 203(2):665-679. https://doi.org/10.1016/S0012-821X(02)00859 $-2$

Hara Y, Yamaguchi K, Onimaru K, Kadota M, Koyanagi M, Keeley SD, Tatsumi K, Tanaka K, Motone F, Kageyama Y (2018) Shark genomes provide insights into elasmobranch evolution and the origin of vertebrates. Nat EcolEvol 2(11):1761-1771. https://doi. org/10.1038/s41559-018-0673-5

Helly JJ, Levin LA (2004) Global distribution of naturally occurring marine hypoxia on continental margins. Deep Sea Res Part I 51(9):1159-1168. https://doi.org/10.1016/j.dsr.2004.03.009

Hodell DA, Woodruff F (1994) Variations in the strontium isotopic ratio of seawater during the Miocene: Stratigraphic and geochemical implications. Paleoceanography 9(3):405-426. https ://doi.org/10.1029/94PA00292

Ichishima H, Barnes LG, Fordyce RE, Kimura M, Bohaska DJ (1994) A review of kentriodontine dolphins (Cetacea; Deiphinoidea; Kentriodontidae): systematics and biogeography. Island Arc 3(4):486-492. https://doi.org/10.1111/j.1440-1738.1994.tb001 27. $\mathrm{x}$

Ingemmet, (2017) Mapasgeológicos 1:100,000. INGEMMET, Lima

Insel N, Poulsen CJ, Ehlers TA, Sturm C (2012) Response of meteoric $\delta 180$ to surface uplift-implications for Cenozoic Andean Plateau growth. Earth Planet Sci Lett 317:262-272. https://doi. org/10.1016/j.eps1.2011.11.039

Kraus R (1998) The cranium of Piscogavialisjugaliperforatus n. gen, n. sp. (Gavialidae, Crocodylia) from the Miocene of Peru. Paläontologische Z 72(3-4):389-405. https://doi.org/10.1007/BF029 88368

Kuo J (2005) A revision of the genus Heterozostera (Zosteraceae). Aquat Bot 81(2):97-140. https://doi.org/10.1016/j.aquab ot.2004.10.005

Lambert O, Muizon CD (2013) A new long-snouted species of the Miocene pontoporiid dolphin Brachydelphis and a review of the Mio-Pliocene marine mammal levels in the Sacaco Basin, Peru.
J VertebrPaleontol 33(3):709-721. https://doi.org/10.1080/02724 634.2013.743405

Lambert O, Bianucci G, Post K, Muizon CD, Salas-Gismondi R, Urbina M, Reumer J (2010) The giant bite of a new raptorial sperm whale from the Miocene epoch of Peru. Nature 466(7302): 105. https://doi.org/10.1038/nature09067

Lambert O, Bianucci G, Beatty BL (2014) Bony outgrowths on the jaws of an extinct sperm whale support macroraptorial feeding in several stem physeteroids. Naturwissenschaften 101(6):517-521. https://doi.org/10.1007/s00114-014-1182-2

Lambert O, Collareta A, Landini W, Post K, Ramassamy B, Di Celma C, Urbina M, Bianucci G (2015) No deep diving: evidence of predation on epipelagic fish for a stem beaked whale from the Late Miocene of Peru. Proc R Soc Biol Sci 282(1815):20151530. https://doi.org/10.1098/rspb.2015.1530

Lambert O, Bianucci G, Muizon CD (2016) Macroraptorial sperm whales (Cetacea, Odontoceti, Physeteroidea) from the Miocene of Peru. Zool J Linn Soc 179(2):404-474. https://doi. org/10.1111/zoj.12456

Lambert O, Bianucci G, Urbina M, Geisler JH (2017) A new inioid (Cetacea, Odontoceti, Delphinida) from the Miocene of Peru and the origin of modern dolphin and porpoise families. Zool J Linn So 179(4):919-946. https://doi.org/10.1111/zoj.12479

Lambert O, Collareta A, Benites-Palomino A, Di Celma C, Muizon CD, Urbina M, Bianucci G (2020) A new small, mesorostrine inioid (Ctacea, Odontoceti, Delphinida) from four late Miocene localities of the Pisco Formation. Pap Palaeontol. https://doi. org/10.1002/spp2.1332

Lambert O, Muizon CD, Urbina M, Bianucci G (2020) A new longirostrine sperm whale (Cetacea, Physeteroidea) from the lower Miocene of the Pisco Basin (southern coast of Peru). J Syst Palaentol 18(20):1707-1742. https://doi.org/10.1080/14772 019.2020 .1805520

Landini W, Altamirano-Sierra A, Collareta A, Di Celma C, Urbina M, Bianucci G (2017a) The late Miocene elasmobranch assemblage from Cerro Colorado (Pisco Formation, Peru). J S Am Earth Sci 73:168-190. https://doi.org/10.1016/j.jsames.2016.12.010

Landini W, Collareta A, Pesci F, Di Celma C, Urbina M, Bianucci G (2017b) A secondary nursery area for the copper shark Carcharhinusbrachyurus from the late Miocene of Peru. J S Am Earth Sci 78:164-174

León WR, Rosell W, Alemán AM, Torres VR, De la Cruz MO (2008) Estratigrafía, sedimentología y evolución tectónica de la cuenca Pisco Oriental. Boletín INGEMMET 27:1-154

Macharé J (1987) La Marge Continentale du Pérou: Régimes Tectoniques et Sédimentaires Cénozoiques de L'avant-Arc des Andes Centrales. PhD Thesis, Universite de Paris Sud, Paris, France, pp 391

Macharé J, Ortlieb L (1992) Plio-Quaternary vertical motions and the subduction of the Nazca Ridge, central coast of Peru. Tectonophysics 205(1-3):97-108. https://doi.org/10.1016/00401951(92)90420-B

Macharé J, Sébrier M, Huaman D, Mercier J (1986) Tectónica cenozoica de la margen continental peruana: Boletín de la Sociedad Geológica del Perú 76:45-77.

Marocco R, Muizon CD (1988) Los vertebrados del Neogeno de la costa sur del Perú: ambientesedimentario y condiciones de fosilización. Bull l'InstitutFrançaisd'étudesAndines 17(2):105-117

Marty RC (1989) Stratigraphy and chemical sedimentology of Cenozoic biogenic sediments from the Pisco and Sechura basins, Peru. Doctoral Thesis, Rice University, Houston, Texas, pp 301

Marx FG, Uhen MD (2010) Climate, critters, and cetaceans: Cenozoic drivers of the evolution of modern whales. Science 327(5968):993-996. https://doi.org/10.1126/science.1185581 
Marx FG, Lambert O, Muizon CD (2017) A new Miocene baleen whale from Peru deciphers the dawn of cetotheriids. R Soc Open Sci 4(9): 170560. https://doi.org/10.1098/rsos.170560

McArthur J, Howarth R, Shields G (2012) Strontium isotope stratigraphy. Geol Time Scale 1:127-144. https://doi.org/10.1016/B9780-444-59425-9.00007-X

Mcdonald HG, Muizon CD (2002) The cranial anatomy of Thalassocnus (Xenarthra, Mammalia), a derived nothrothere from the Neogene of the Pisco Formation (Peru). J VertebrPaleontol 22(2):349-365. https://doi.org/10.1671/02724634(2002)022\%5B0349:TCAOTX\%5D2.0.CO;2

Miller KG, Mountain GS, Wright JD, Browning JV (2011) A 180-million-year record of sea level and ice volume variations from continental margin and deep-sea isotopic records. Oceanography 24(2):40-53. https://doi.org/10.5670/oceanog.2011.26

Muizon CD (1978) Arctocephalus (Hydrarctos) lomasiensis, subgen, nov. et nov. sp., un nouvelOtariidae du Mio-Pliocene de Sacaco (Perou). Bull de l'InstitFrancais des Etudes Andines 7(3-4):169-188

Muizon CD (1981) Les vertébrés fossiles de la formation Pisco (Pérou). ADPF, Washington

Muizon CD (1988) Les relations phylogenetiques des Delphinida (Cetacea, mammalia). Ann de Paléontol 74(4):159-227

Muizon CD, Bellon H (1980) L'âge mio-pliocène de la Formation Pisco (Pérou). Comptes Rendus de l'Acad des Sci de Paris 52:1063-1066

Muizon CD, Bellon H (1986) Nouvellesdonnéessurl'âge de la Formation Pisco (Pérou). Comptesrendus de l'Académie des sciences. Série 2 Mécanique Physique Chimie Sci de l'univers Sci de la Terre 303(15):1401-1404

Muizon CD, DeVries TJ (1985) Geology and paleontology of late Cenozoic marine deposits in the Sacaco area (Peru). Geol Rundsch 74(3):547-563. https://doi.org/10.1007/BF01821211

Muizon CD, Domning D (1985) The first records of fossil sirenians in the southeastern Pacific Ocean. Bull du Muséum Natl d'histoire Naturelle 7(3):189-213

Muizon CD, Domning H (2002) The anatomy of Odobenocetops (Delphinoidea, Mammalia), the walrus-like dolphin from the Pliocene of Peru and its palaeobiological implications. Zool J Linn Soc 134(4):423-452. https://doi.org/10.104 6/j.1096-3642.2002.00015.x

Muizon CD, McDonald H (1995) An aquatic sloth from the Pliocene of Peru. Nature 375(6528):224-227

Muizon CD, Mcdonald HG, Salas-Gismondi R, Urbina M (2003) A new early species of the aquatic sloth Thalassocnus (Mammalia, Xenarthra) from the Late Miocene of Peru. J Vertebr Paleontol 23(4):886-894. https://doi.org/10.1671/2361-13

Muizon CD, McDonald HG, Salas-Gismondi R, Urbina M (2004a) The evolution of feeding adaptations of the aquatic sloth Thalassocnus. J Vertebr Paleontol 24(2):398-410. https://doi. org/10.1671/2429b

Muizon CD, McDonald HG, Salas-Gismondi R, Urbina M (2004b) The youngest species of the aquatic sloth Thalassocnus and a reassessment of the relationships of the nothrothere sloths (Mammalia: Xenarthra). J Vertebr Paleontol 24(2):387-397. https:// doi.org/10.1671/2429a

Murakami M, Shimada C, Hikida Y, Soeda Y, Hirano H (2014) Eodelphiskabatensis, a new name for the oldest true dolphin StenellakabatensisHorikawa, 1977 (Cetacea, Odontoceti, Delphinidae), from the upper Miocene of Japan, and the phylogeny and paleobiogeography of Delphinoidea. J VertebrPaleontol 34(3):491511. https://doi.org/10.1080/02724634.2013.816720

Newell N (1956) Reconocimiento geológico de la región Pisco-Nazca. Bol Soc Soc Geol del Perú 30:261-295

Norris KS, Mohl B (1983) Can odontocetes debilitate prey with sound? Am Nat 122(1):85-104. https://doi.org/10.1086/284120
Parham JF, Pyenson ND (2010) New sea turtle from the Miocene of Peru and the iterative evolution of feeding ecomorphologies since the Cretaceous. J Paleontol 84(2):231-247. https://doi. org/10.1666/09-077R.1

Paulmier A, Ruiz-Pino D (2009) Oxygen minimum zones (OMZs) in the modern ocean. Prog Oceanogr 80(3-4):113-128. https://doi. org/10.1016/j.pocean.2008.08.001

Pauly D, Trites A, Capuli E, Christensen V (1998) Diet composition and trophic levels of marine mammals. ICES J Mar Sci 55(3):467-481. https://doi.org/10.1006/jmsc.1997.0280

Pennington JT, Mahoney KL, Kuwahara VS, Kolber DD, Calienes R, Chavez FP (2006) Primary production in the eastern tropical Pacific: a review. Prog Oceanogr 69(2-4):285-317. https://doi. org/10.1016/j.pocean.2006.03.012

Petersen G (1954) Informe preliminar sobre la geología de la faja costanera del Departamento de Ica, Boletín Técnico Empresa Petrolera Fiscal, n.1. pp 33-41

Phillips R, Wyllie-Escheverria S, DeVries TJ (1996) Fossil Heterozostera tasmanica from south-central Peru, Seagrass Biology. In: Proceedings of an International Workshop, Rottnest, Island, Western Australia, pp 369

Pilleri G, Siber H (1989) Neuerspättertiärercetotherid (Cetacea, Mysticeti) aus der Pisco Formation Perus. Beiträge zur Paläontologie der CetaceenPerus 1:108-122

Pimiento C, Balk MA (2015) Body-size trends of the extinct giant shark Carcharocles megalodon: a deep-time perspective on marine apex predators. Paleobiology 41(3):479-490. https://doi. org/10.1017/pab.2015.16

Pimiento C, Griffin JN, Clements CF, Silvestro D, Varela S, Uhen MD, Jaramillo C (2017) The Pliocene marine megafauna extinction and its impact on functional diversity. Nat EcolEvol 1(8):1100 1106. https://doi.org/10.1038/s41559-017-0223-6

Poulsen CJ, Ehlers TA, Insel N (2010) Onset of convective rainfall during gradual late Miocene rise of the central Andes. Science 328(5977):490-493. https://doi.org/10.1126/science.1185078

Pyenson ND, Vermeij GJ (2016) The rise of ocean giants: maximum body size in Cenozoic marine mammals as an indicator for productivity in the Pacific and Atlantic Oceans. Biol Lett 12(7):20160186. https://doi.org/10.1098/rsbl.2016.0186

Pyenson ND, Gutstein CS, Parham JF, Le Roux JP, Chavarría CC, Little H, Metallo A, Rossi V, Valenzuela-Toro AM, Velez-Juarbe J (2014) Repeated mass strandings of Miocene marine mammals from Atacama Region of Chile point to sudden death at sea. Proc R Soc B 281(1781):20133316. https://doi.org/10.1098/ rspb.2013.3316

Quispe K, Baby P, Calderón Y, Hurtado C, Ramírez L (2018) La Cuenca Pisco: Nuevo Modelo Estructural para una Cuenca de Antearco Peruana, Evidencias de Contexto Compresivo, Desarrollo de la Cordillera de la Costa, XIX Congreso Peruano de Geología. SGP Lima Peru. https://doi.org/10.13140/ RG.2.2.11140.68483

Rabosky DL (2014) Automatic detection of key innovations, rate shifts, and diversity-dependence on phylogenetic trees. PLoS ONE. https://doi.org/10.1371/journal.pone.0089543

Rustichelli A, Di Celma C, Tondi E, Bianucci G (2016) Deformation within the Pisco Basin sedimentary record (southern Peru): Stratabound orthogonal vein sets and their impact on fault development. J S Am Earth Sci 65:79-100. https://doi.org/10.1016/j. jsames.2015.11.002

Salas-Gismondi R, Moreno-Bernal JW, Scheyer TM, SánchezVillagra MR, Jaramillo C (2019) New Miocene Caribbean gavialoids and patterns of longirostry in crocodylians. J SystPaleontol 17(12):1049-1075. https://doi.org/10.1080/14772 019.2018.1495275

Salvatteci R, Gutiérrez D, Field D, Sifeddine A, Ortlieb L, Bouloubassi I, Boussafir M, Boucher H, Cetin F (2014) The response of the 
Peruvian Upwelling Ecosystem to centennial-scale global change during the last two millennia. Clim Past 10(2):715-731. https:// doi.org/10.5194/cp-10-715-2014

Salvatteci R, Gutierrez D, Sifeddine A, Ortlieb L, Druffel E, Boussafir M, Schneider R (2016) Centennial to millennial-scale changes in oxygenation and productivity in the Eastern Tropical South Pacific during the last 25,000 years. Quatern Sci Rev 131:102117. https://doi.org/10.1016/j.quascirev.2015.10.044

Scaffidi B, Tung TA, Gordon G, Alaica AK, González La Rosa LM, Marsteller SJ, Dahlstedt AL, Schach E, Knudson KJ (2020) Drinking Locally: a Water 87Sr/86Sr Isoscape for Geolocation of Archeological Samples in the Peruvian Andes. Front Ecol Evol. https://doi.org/10.3389/fevo.2020.00281

Schrader H, Ronning P (1988) Diatom biostratigraphy and coastal upwelling interpretation. Cenozoic Geology of the Pisco Basin. IGCP 156:135-140

Schrader H, Sorknes R (1991) Peruvian coastal upwelling: Late Quaternary productivity changes revealed by diatoms. Mar Geol 97(3-4):233-249

Sepulchre P, Sloan LC, Snyder M, Fiechter J (2009) Impacts of Andean uplift on the Humboldt Current system: a climate model sensitivity study. Paleoceanography. https://doi.org/10.1029/2008P A001668

Shimada K (2002) The relationship between the tooth size and total body length in the white shark. J Foss Res 35(2):28-33. https:// doi.org/10.3390/geosciences2020109

Shimada K (2019) The size of the megatooth shark, Otodus megalodon (Lamniformes: Otodontidae), revisited. Hist Biol. https://doi. org/10.1080/08912963.2019.1666840

Short F, Carruthers T, Dennison W, Waycott M (2007) Global seagrass distribution and diversity: a bioregional model. J Exp Mar Biol Ecol 350(1-2):3-20. https://doi.org/10.1016/j.jembe .2007 .06 .012

Simpson GG (1960) Notes on the measurement of faunal resemblance. Am J Sci 258(2):300-311

Solis F (2018) Bioestratigrafía e implicancias paleoceanográfica de las diatomeas de la sección Cerro Caucato, Formación Pisco, Ica, Perú. Master Thesis, Universidad Peruana Cayetano Heredia, Lima, Peru, pp 125

Steeman ME, Hebsgaard MB, Fordyce RE, Ho SY, Rabosky DL, Nielsen R, Rahbek C, Glenner H, Sørensen MV, Willerslev E (2009) Radiation of extant cetaceans driven by restructuring of the oceans. Syst Biol 58(6):573-585. https://doi.org/10.1093/ sysbio/syp060

Stock C (1990) Tertiary Geology of the Quebrada Huaricangana Area, East Pisco Basin, Southern Peru: Late Paleogene to Neogene Trangressive sedimentation within a forearc basin. Master Thesis, Rice University, Houston, Texas, pp 198

Stucchi M (2002) Una nuevaespecie de Spheniscus (Aves: Spheniscidae) de la formaciónPisco, Perú. Boletín de la SociedadGeológica del Perú 94:17-24. https://doi.org/10.4000/bifea.6488

Stucchi M (2007) Los pingüinos de la formación Pisco (Neógeno), Perú, 4th European Meeting on the Palaeontology and Stratigraphy of Latin America Cuadernos del Museo Geominero. Instituto Geológico y Minero de España, Madrid, pp 367-373

Stucchi M, Emslie SD (2005) A new condor (Ciconiiformes, Vulturidae) from the late Miocene/early Pliocene Piscoformation,Peru. Condor 107(1):107-113. https://doi.org/10.1650/7475

Stucchi M, Urbina M (2004) Ramphastosula (Aves, Sulidae): a new genus from the early Pliocene of the Pisco Formation, Peru. J VertebrPaleontol 24(4):974-978. https://doi.org/10.1671/02724634(2004)024[0974:RASANG]2.0.CO;2

Stucchi M, Emslie SD, Varas-Malca RM, Urbina-Schmitt M (2015a) A new Late Miocene condor (Aves, Cathartidae) from Peru and the origin of South American condors. J VertebrPaleontol 35(5):e972507. https://doi.org/10.1080/02724634.2015.972507
Stucchi M, Varas-Malca RM, Urbina-Schmitt M (2015b) New Miocene sulid birds from Peru and considerations on their Neogene fossil record in the Eastern Pacific Ocean. Acta Palaeontol Pol 61(2):417-427

Stucchi M, Varas-Malca RM, Urbina-Schmitt M (2016) New Miocene sulid birds from Peru and considerations on their Neogene fossil record in the Eastern Pacific Ocean. Acta Palaeontol Pol 61(2):417-428. https://doi.org/10.4202/app.00170.2015

Tarazona J, Arntz W (2001) The Peruvian coastal upwelling system. In: Seeliger U, Kjerfve B (eds) Coastal marine ecosystems of Latin America. Springer, Berlin, pp 229-244

Tarazona J, Gutiérrez D, Paredes C, Indacochea A (2003) Una revisión y desafíos para la investigación en biodiversidad marina en Perú. Gayana (Concepción) 67(2):206-231

Tarquini J, Soibelzon LH, Salas-Gismondi R, Muizon CD (2020) Cyonasua (Carnivora, Procyonidae) from late Miocene of Peru shed light on the early dispersal of carnivorans in South America. J Vertebr Paleontol 40(5):e1834406. https://doi.org/10.1080/02724 634.2020.1834406

Thiel M, Macaya E, Acuña E, Arntz W, Bastias H, Brokordt K, Camus P, Castilla J, Castro L, Cortés M, Dumont C, Escribano R, Fernandez M, Gajardo J, Gaymer C, Gomez I, González A, González H, Haye P, Illanes J-E, Iriarte J, Lancellotti D, LunaJorquera G, Luxoro C, Manriquez P, Marín V, Muñoz P, Navarrete S, Perez E, Poulin E, Sellanes J, Sepúlveda H, Stotz W, Tala F, Thomas S, Vargas C, Vasquez J, Alonso J (2007) The Humboldt current system of northern and central Chile. Oceanogr Mar Biol Annu Rev 45:195-344

Thorbjarnarson JB (2010) American crocodile Crocodylus acutus. Crocodiles. Status survey and conservation action plan, pp46-53

Thornburg T, Kulm L (1981) Sedimentary basins of the Peru continental margin: Structure, stratigraphy, and Cenozoic tectonics from $6 \mathrm{~S}$ to $16 \mathrm{~S}$ latitude. GeolSoc Am Mem 154:393-422

Toggweiler J, Dixon K, Broecker W (1991) The Peru upwelling and the ventilation of the South Pacific thermocline. J Geophys Res 96(C11):20467-20497. https://doi.org/10.1029/91JC02063

Travis RB, Gonzales G, Pardo A (1976) Hydrocarbon potential of coastal basins of Peru: hydrocarbons. In: Halbouty M, Maher $\mathrm{J}$, Lian H (eds) Circum-pacific energy and mineral resources. American Association of Petroleum Geologists Memoir, Tulsa, pp 331-338. https://doi.org/10.1306/M25386

Tucker MA, Rogers TL (2014) Examining predator-prey body size, trophic level and body mass across marine and terrestrial mammals. Proce R Soc Biol Sci 281(1797):20142103. https://doi. org/10.1098/rspb.2014.2103

Uhen MD, Pyenson ND (2007) Diversity estimates, biases, and historiographic effects: resolving cetacean diversity in the Tertiary. Palaeontol Electron 10(2): 1-22

Urbina M, Stucchi M (2005) Evidence of a fossil stork (Aves: Ciconiidae) from the late Miocene of the Pisco Formation, Peru. Boletin de la SociedadGeológica del Perú 100(2):63-66

Valenzuela-Toro AM, Gutstein CS, Suárez ME, Otero R, Pyenson ND (2015) Elephant seal (Miroungasp) from the Pleistocene of the Antofagasta Region, northern Chile. J VertebrPaleontol 35(3):e918883. https://doi.org/10.1080/02724634.2014.918883

Velez-Juarbe J, Domning DP, Pyenson ND (2012) Iterative evolution of sympatric seacow (Dugongidae, Sirenia) assemblages during the past 26 million years. PLoS ONE 7(2):e31294-e31294. https:// doi.org/10.1371/journal.pone.0031294

Villafaña JA, Rivadeneira MM (2014) Rise and fall in diversity of Neogene marine vertebrates on the temperate Pacific coast of South America. Paleobiology 40(4):659-674. https://doi. org/10.1666/13069

Viveen W, Schlunegger F (2018) Prolonged extension and subsidence of the Peruvian forearc during the Cenozoic. Tectonophysics 730:48-62. https://doi.org/10.1016/j.tecto.2018.02.018 
Walsh S, Naish D (2002) Fossil seals from late Neogene deposits in South America: a new pinniped (Carnivora, Mammalia) assemblage from Chile. Palaeontology 45(4):821-842. https://doi. org/10.1111/1475-4983.00262

Walsh SA, Suárez M (2005) First post-Mesozoic record of Crocodyliformes from Chile. Acta Palaeontol Pol 50(3):595-600

Wara MW, Ravelo AC, Delaney ML (2005) Permanent El Niñolike conditions during the Pliocene warm period. Science 309(5735):758-761. https://doi.org/10.1126/science.1112596

Werth AJ (2006) Odontocete suction feeding: experimental analysis of water flow and head shape. J Morphol 267(12):1415-1428. https ://doi.org/10.1002/jmor.10486
Whitsett RM (1976) Gravity measurements and their structural implications for the continental margin of southern Peru. PhD Thesis, Oregon State University, USA, pp 82

Zachos J, Pagani M, Sloan L, Thomas E, Billups K (2001) Trends, rhythms, and aberrations in global climate 65 Ma to present. Science 292(5517):686-693. https://doi.org/10.1126/science.10594 12

Zhang YG, Pagani M, Liu Z (2014) A 12-million-year temperature history of the tropical Pacific Ocean. Science 344(6179):84-87. https://doi.org/10.1126/science.1246172 